TI 2018-040/V

Tinbergen Institute Discussion Paper
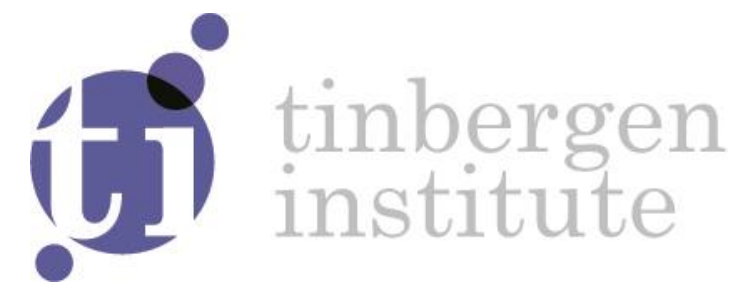

\title{
Does price competition damage healthcare quality?
}

\author{
Anne-Fleur Roos ${ }^{1}$ \\ Eddy van Doorslaer ${ }^{2}$ \\ Owen O'Donnell ${ }^{3}$ \\ Erik Schut ${ }^{4}$ \\ Marco Varkevisser ${ }^{5}$
}

\footnotetext{
${ }^{1}$ Erasmus School of Health Policy \& Management (ESHPM), Erasmus University Rotterdam (EUR)

${ }^{2}$ ESHPM \& Erasmus School of Economics (ESE), EUR, Tinbergen Institute (TI)

${ }^{3}$ ESE, EUR, TI, University of Macedonia

${ }^{4}$ ESHPM, EUR

${ }^{5}$ ESHPM, EUR
} 
Tinbergen Institute is the graduate school and research institute in economics of Erasmus University Rotterdam, the University of Amsterdam and VU University Amsterdam.

Contact: discussionpapers@tinbergen.nl

More TI discussion papers can be downloaded at http://www.tinbergen.nl

Tinbergen Institute has two locations:

Tinbergen Institute Amsterdam

Gustav Mahlerplein 117

1082 MS Amsterdam

The Netherlands

Tel.: +31(0)205984580

Tinbergen Institute Rotterdam

Burg. Oudlaan 50

3062 PA Rotterdam

The Netherlands

Tel.: +31(0)10408 8900 


\title{
Does Price Competition Damage Healthcare Quality?
}

\author{
Anne-Fleur Roos, Eddy van Doorslaer, Owen O'Donnell, \\ Frederik Schut \& Marco Varkevisser*
}

\begin{abstract}
April 2018
Abstract

One of the reasons why regulators are hesitant about permitting price competition in healthcare markets is that it may damage quality when information is poor. Evidence on whether this fear is well-founded is scarce. We provide evidence using a reform that permitted Dutch health insurers and hospitals to freely negotiate prices for elective procedures. Unlike previous research that has relied on indicators of the quality of urgent treatments, we take advantage of the plausible absence of selection bias in our setting to identify the effect on quality of non-acute hip replacements. Using administrative data on all admissions to Dutch hospitals, we find no evidence that increased exposure to price competition reduces quality measured by readmission rates, despite the lack of publicly available information on this outcome. In fact, there is evidence of a temporary, positive impact on quality. Our estimated null effect over the full post-liberalization period is robust.
\end{abstract}

JEL: I11, L14, L15

Keywords: Health care; hospital; competition; quality; contracting

\section{Acknowledgements}

The authors would like to thank Dutch Hospital Data and Statistics Netherlands for providing access to the data. We are grateful for comments received from Pieter Bakx, Werner Brouwer, Carol Propper, Ellen van Rooijen, Ben Scharp, Anthony Scott, Matthew Skellern, Wynand van de Ven, and participants at various seminars and coneferences.

* Anne-Fleur Roos (corresponding author): Erasmus School of Health Policy \& Management (ESHPM), Erasmus University Rotterdam (EUR), roos@eshpm.eur.nl. Eddy van Doorslaer: ESHPM \& Erasmus School of Economics (ESE), EUR, Tinbergen Institute (TI), vandoorslaer@ese.eur.nl. Owen O’Donnell: ESE, EUR, TI \& University of Macedonia, odonnell@ese.eur.nl. Frederik Schut: ESHPM, EUR, schut@eshpm.eur.nl. Marco Varkevisser: ESHPM, EUR, varkevisser@eshpm.eur.nl. 


\section{Introduction}

Health systems around the world are increasingly designed to encourage competition between providers in the hope that this will improve quality of care while slowing the growth of health spending (Propper, 2011). When prices are regulated, providers are forced to compete on quality to attract patients or contracts with insurers. But when prices are unregulated, the effect of competition on quality is less clear. If demand is more responsive to price than to quality, then the optimal competitive strategy will involve driving down the price and sacrificing quality (Gaynor, 2006). This is a plausible scenario when information on quality is poor, much of the variation in quality is unobservable and so demand is insensitive to it. However, not-for-profit healthcare providers may not adopt the most competitive strategy. Their intrinsic motivation may lead them to maintain quality even if this means forgoing opportunities to gain a competitive advantage by cutting prices at the expense of quality. Whether quality suffers in competitive healthcare markets with unregulated prices is an empirical question. To date, evidence to answer it is sparse. A highly regulated form of price competition introduced in the UK National Health Service (NHS) at a time when there was poor information on quality was found to be (weakly) associated with worse health outcomes from hospital treatment (Propper et al., 2008; 2004). Health outcomes also deteriorated in one US state when prices were deregulated in the hospital care market (Volpp et al., 2003). However, policy and market changes that occurred at the same time as the deregulation may have confounded the effect of deregulating prices.

This paper presents evidence on the impact of unconstrained price competition on the quality of hospital care delivered in the Dutch healthcare market in which insurers compete

for customers and providers compete for contracts with insurers. We estimate the effect of moving from financing hospitals though prospective budgeting to allowing insurers and hospitals to freely negotiate prices in contracts for the delivery of certain medical procedures. We identify the effect of this price liberalization by exploiting variation in its consequences across hospitals differentiated by the concentration of the market in which they operate. Assuming that free negotiation of prices creates greater competitive pressure where the market is less concentrated, difference-in-differences (DID) across more and less concentrated markets can identify the effect of liberalizing prices and this can be interpreted as the effect of exposure to greater price competition. This is similar to the approach taken by Propper et al. (2008), Cooper et al. (2011) and Gaynor et al. (2013) to evaluate impact of competition in the UK NHS. 
Most studies of the impact of hospital competition use mortality after acute myocardial infarction (AMI) as an indicator of quality (see e.g. Cooper et al., 2011; Gaynor et al., 2013; Kessler \& Geppert, 2005; Mutter et al., 2011; Romano \& Balan, 2011). The reason is that the urgency of AMI treatment greatly reduces the risk of selection bias. Patients are taken to the nearest hospital, which is obliged to treat them. There is little or no opportunity for difficultto-treat patients selecting hospitals that deviate from the average in both quality and exposure to competition. And there is little scope for those hospitals to cherry pick the easier cases. The downside of this empirical strategy is that it identifies the impact of competition on the quality of a treatment that is demand inelastic with respect to quality. It identifies the impact of competition on quality only in so far as the pressure to compete in the delivery of some procedures affects the general management of a hospital and this feeds through to treatments, such as AMI, that are largely shielded from competition. This leaves us with little or no evidence on the effect of competition on treatments, such as elective surgeries, that hospitals directly compete for and that potentially exhibit much greater demand sensitivity to quality than is true of urgent procedures (Skellern, 2017; Gravelle et al., 2014; Bevan \& Skellern, 2011). Provided quality is sufficiently observable, competition has the potential to impact more positively on the quality of elective surgery than on the quality of acute surgery (Colla et al., 2016).

We present evidence of the impact of competition on the quality of a procedure -- nonacute hip replacements - over which hospitals directly compete, including through freely negotiated prices. We use unplanned readmission rates to indicate quality. Higher readmission rates following hip replacement have been shown to be related to suboptimal quality (e.g. Rosen et al., 2013; Mokhtar et al., 2012). In England, providers facing more competition were found to face a more elastic demand with respect to quality (and waiting times) for elective hip replacements than providers facing less competition (Moscelli et al., 2016).

The institutional context and our empirical strategy give us the option to identify the effect of competition on the quality of an elective procedure without running much risk of selection bias. Previous studies, particularly those of the UK NHS, have identified the impact of competition by exploiting reforms that intensified competitive pressure through increasing the scope for patient choice of the provider (Cooper et al., 2011 and Gaynor et al., 2013). These studies avoided using outcomes of elective procedures to measure quality because of the considerable potential for selection bias. The Dutch healthcare market reform we exploit introduced price competition but left patient choice unaffected. Before and after the liberalization of prices patients and insurers had unconstrained choice of provider. But the 
absence of any information on hip replacement readmission rates made it impossible for patients and insurers to select a hospital on the basis of the outcome. Further, to identify the effect of competition we separate hospitals into two broad (treatment/comparison) groups according to the concentration of the market in which they operate. If there was any selection correlated with the outcome, it would most likely involve switching between neighboring hospitals that will belong to the same group, which would not induce selection bias given our strategy. Baseline patient characteristics are similar across the treatment and comparison groups, changes in these characteristics do not differ between the groups and conditioning on these characteristics has little or no impact on the estimates. If the estimates are insensitive to conditioning observables, it is unlikely that they are even moderately biased by correlated unobservables.

Given that information on the quality of hospital care was absent at the time free price negotiation was introduced in the Dutch hospital market, there was a risk of a negative impact on quality if hospitals competed on price and neglected quality. We find no evidence of this. Our main point estimate is that exposure to price competition reduced the 90-day readmission rate of hospitals in less concentrated markets by almost 1 percentage point (baseline: 8.2 percent) compared with hospitals in more concentrated markets that were exposed to less competitive pressure. But this estimate is not significantly different from zero. In the year immediately after prices were liberalized, we estimate that increased exposure to competition did significantly $(p$-value $=0.02)$ reduce the readmission rate. The finding that there was no significant, effect that persisted over the full post-reform period is robust to different definitions of market size and to using the 30-day, rather than 90-day, readmission rate. Hence, although competition was introduced in the market for a potentially demand sensitive elective procedure and information on its quality was absent when prices were made freely negotiable, the quality of care does not seem to have suffered. If anything, there was a temporary improvement in quality. While it is merely speculation, one possible explanation for this is that providers, who were contracting for the delivery of specific procedures for the first time, initially did not appreciate the extent to which insurers would focus on price in the (re)negotiation of contacts. Consequently, the hospitals exposed to greater competitive pressure were careful to maintain, or even improve, quality in the first year operating under the new contracting regime. Only later, when they witnessed insurers' preoccupation with price, did they also concentrate on competing in that domain. More concretely, our study provides evidence that price competition in healthcare markets is not necessarily always at the expense of quality, even when information on quality is poor. 


\section{Competition and healthcare quality with unregulated prices: theory and evidence}

When prices are unregulated, the impact of competition on quality depends on how it affects the responsiveness of demand to quality relative to price. If consumers or insurers observe prices but have only imperfect information on quality, then competition might be expected to raise the price sensitivity relative to the quality sensitivity of demand, and so reduce quality. Gaynor (2006) makes this argument using an amended version of the Dorfman-Steiner condition (Dorfman \& Steiner, 1954): $z=\frac{p}{d} \cdot \frac{\varepsilon_{z}}{\varepsilon_{p}}$ where $z$ is quality, $p$ is price, $d$ is the marginal cost of quality, $\varepsilon_{z}$ is the elasticity of demand with respect to quality and $\varepsilon_{p}$ is the elasticity with respect to price ${ }^{1}$. If competition exerts downward pressure on the price relative to the marginal cost and/or raises the magnitude of the price elasticity relative to the quality elasticity, then it will reduce quality (Gaynor et al., 2015). However, if quality becomes sufficiently observable, then competition could conceivably raise the quality elasticity relative to the price elasticity. Quality would increase, provided price does not fall relative to the marginal cost of quality.

In the Netherlands, as in most high-income countries, consumers of healthcare can be expected to be rather price insensitive because of comprehensive health insurance with limited cost sharing. However, this does not imply that demand is perfectly price inelastic. Health insurers are sensitive to prices (Gowrisankaran et al., 2015). The reform we use for identification was intended to make insurers more price sensitive. It gave them the freedom to negotiate prices for specific procedures with individual hospitals. This price liberalization would be expected to increase the price elasticity of the insurers' demand and push prices downward. According to the Dorfman-Steiner condition, quality would then suffer unless there was a sufficient countervailing increase in the quality elasticity ${ }^{2}$. This would occur only if quality was sufficiently observable such that insurers could monitor it and the new contracting arrangements gave them greater motivation and scope to pressure hospitals for quality improvements.

The complexity of healthcare and its stochastic relationship with health outcomes makes measurement of its quality inherently difficult. This, together with a lack of published

\footnotetext{
${ }^{1}$ Although Dorfman \& Steiner (1954) model a monopolist's behaviour, Dranove and Satterthwaite (2000) show that the model is an approximation to the behaviour of an oligopolistic or monopolistically competitive firm if we think of the demand function as a reduced form demand. Hence, the model has relevance for imperfectly competitive healthcare markets (Gaynor, 2006; Gaynor et al., 2015).

${ }^{2}$ It is unlikely that hospitals deliberately set out to lower quality of care. Studies that investigate the competition-quality relationship often assume that in response to competitive pressure, hospitals cut services that affect quality outcomes (Propper et al., 2008; Bloom et al., 2015). Nonetheless, models on the relationship between competition and quality assume a direct relationship between competition and quality rather than between competition and effort. Gaynor and Town (2012) show that for the purpose of modeling the distinction between effort and quality of care is irrelevant. A given service level generates an expected level of outcome of care (e.g. mortality or a readmission) and therefore it does not matter whether a model assumes hospitals to choose quality of services or any other outcome (Gaynor \& Town, 2012).
} 
information on hospital quality both before and after the reform we examine, would be expected to result in hospitals exposed to greater competitive pressure shifting effort from maintaining poorly observed quality to cutting costs in order to become more price competitive (Propper et al., 2008). On the other hand, the new contracts involved hospitals and insurers negotiating for the first time over the delivery of specific procedures akin to diagnostic-related groups. Hospitals exposed to more competition might have exerted greater effort in improving the quality of these procedures for fear of losing a contract. Without experience of the weight the insurers would place on price relative to quality in contract renewal negotiations, the hospitals may have been motivated, at least initially, to ensure that price competitiveness was not achieved at the cost of quality. If this motivation was sufficiently strong, then potentially competition could even have raised quality. The effect of price competition on quality is therefore ambiguous. It depends on characteristics of the market, the observability of quality and the objective functions of the insurers and hospitals (Gaynor et al., 2015).

Evidence on the effect of price competition on healthcare quality is scarce ${ }^{3}$. This is mainly because only a few countries permit free price negotiation in healthcare markets and data on the performance of private healthcare providers are typically not accessible. Using data from Southern California, Gowrisankaran and Town (2003) find that increased competition for Health Maintenance Organization (HMO) patients is correlated with reduced risk-adjusted hospital mortality for both pneumonia and AMI. Consistent with this, Sari (2002) uses a similar methodology based on the Structure-Conduct-Performance (SCP) framework and finds that increased competition (lower hospital market share and market concentration) in 16 US states is associated with fewer hospital complications. However, the internal validity of these studies can be doubted because of endogeneity problems that are known to beset the SCP approach (Gaynor \& Town, 2012), and their external validity is limited because the HMO markets studied are very particular to the US hospital market in the 1990s.

The few studies that exploit a policy change to identify the quality effect of a change in price competition are stronger with respect to internal validity but also difficult to generalize because the findings are obtained in specific settings with a particular design of price competition. Subject to this caveat, these studies generally find that price competition does damage hospital quality. Volpp et al. (2003) compare AMI mortality rates of New Jersey

\footnotetext{
${ }^{3}$ There is more evidence on the impact of competition on quality when prices are regulated. Findings are mixed. Some studies find that competition improves quality in this context (Cooper et al., 2011; Gaynor et al., 2016; Gaynor et al., 2013; Gobillon \& Milcent, 2017; Kessler \& Geppert, 2005; Kessler \& McClellan, 2000; Propper et al., 2010), others find evidence of the contrary (Moscelli et al., 2016b; Skellern, 2017), while one study finds no effect at all (Berta et al., 2016). 
hospitals before and after the deregulation of prices in 1992 with those of New York hospitals where there was no deregulation. However, coincident to the reform, hospital prices were also pressured through rapid growth of large-volume buyers, such as HMOs, and large reductions in subsidies for hospital care of uninsured patients. The mortality rate of uninsured AMI patients increased in New Jersey relative to New York but it is not clear how much, if any, of this was attributable to the price deregulation. The switch from fixed budgets that hospitals received directly from the national government to negotiating over contracts with purchasing organizations in the British NHS in 1991 has been used to estimate the quality effect of a highly regulated form of price competition (Propper et al., 2004; 2008). The competition was highly regulated since contracts were written for blocks of services, including accident and emergency procedures and not for defined procedures, such as DRGs, and hospitals were not free to set prices. They were mandated to set price equal to average costs, had to publish the price and were not permitted to carry surpluses or losses across financial years. However, some form of price competition was possible at the specialty level because arbitrary apportionment of costs to a particular service made it difficult for the regulator to check on adherence to the pricing rule at that level (Propper et al., 2008). There is some evidence that prices in this period were indeed not solely determined by costs but were related to market forces (Propper, 1996). The evidence suggests that even this regulated form of price competition had a negative impact on quality (measured by AMI mortality rates), which is attributed to incentives for hospitals to compete on prices rather than quality when the available information on the latter is poor (Propper et al., 2004; 2008). If this highly regulated form of price competition can damage quality, then entirely free price competition could potentially be seriously detrimental to the quality of care delivered by hospitals. The 2005 liberalization of price setting in the Dutch healthcare market allows us to test this hypothesis. Since there was no quality information available either publicly or to health insurers at the time of the reform, the risk of a negative impact on quality was substantial.

\section{Price competition in the Dutch healthcare market}

All Dutch hospitals are private nonprofit foundations. Before 2005, Dutch hospitals were financed by a prospective budgeting system with relatively stable revenue flows known at the beginning of each year. From 2005, revenues became contingent on contracts secured with individual health insurers. There were five health insurance companies plus a joint purchasing 
cooperative of small health insurers in the market ${ }^{4}$. Hospitals and insurers negotiate over volume and quality of care per product, which is defined by a Diagnosis and Treatment Combination (DTC), the Dutch equivalent of a DRG5 . These DTC products had no relation to the output parameters of the pre-reform hospital budgets (e.g. number of admissions and hospital days). In 2005, free negotiation of price was permitted in writing contracts for a subset of DTCs that accounted for about $10 \%$ of hospital revenues. This included non-acute hip replacements, which is the procedure we use to evaluate the impact of the introduction of price competition on quality. The number of DTCs for which free price setting was permitted was extended over time. In 2008, 20\% of all hospital revenues were obtained from DTCs with negotiated prices. This fraction increased to $34 \%$ in 2009 and $70 \%$ in 2012 . Because of the high overall number of DTCs, insurers and hospitals often negotiate over clusters of DTCs. However, contracting is done separately for high-revenue/high-volume products like nonemergency hip replacements ${ }^{6}$.

The goal of the contracting reform was to make insurers, acting as purchasing agents for their customers, more responsive to price, volume and quality. Health insurers were allowed to contract hospitals selectively, which would enable them to negotiate lower prices with selected hospitals. In a competitive insurance market, these lower prices would feed through to lower premiums (Ho, 2009). A major reform of the health insurance market in 2006 increased price competition among health insurers, which were expected to put pressure on hospitals to cut their costs (Schut \& Van de Ven, 2011). If consumers not only value lower premiums but also access to quality hospitals, then health insurers should compete both on premiums and the scope and quality of their provider networks (Determann et al., 2016). Hospitals are expected to compete on price and quality for inclusion in the insurers' network.

Existing evidence on the market response to the liberalization of prices in Dutch insurerhospital negotiation of contracts is limited. Qualitative examination of insurer-provider contracting suggests that price rather than quality has been the primary focus of the contract negotiations (Meijer et al., 2010; Ruwaard et al., 2014; Schut \& Van de Ven, 2011). This is perhaps unsurprising given the dearth of information available on quality. For example, hospital-specific readmission rates for hip replacement patients - the quality indicator we use - were not available to patients nor insurers during the period we study. The Dutch Healthcare

\footnotetext{
${ }^{4}$ The four largest companies account for 90 percent of the market. Market concentration by region is often even higher, which is due to the fact that these companies typically evolved from former regional sickness funds (Halbersma et al., 2010).

${ }^{5}$ The DTC system is more comprehensive than DRGs. It includes outpatient consultations and the remuneration of medical specialists. There were 29000 DTCs in the period we examine (2005-2007).

${ }^{6}$ This has been confirmed in interviews with representatives of insurers and hospitals involved in contract negotiations during the period we study. 
Authority (NZa, 2009) found that hospital prices increased less in the free-pricing segment of DTCs than in the regulated segment between 2005 and 2008. Between 2006 and 2008 prices in the free-pricing segment even declined in real terms. There is no evidence that hospitals offset lower price increases by increasing service volume in the free-pricing segment (Krabbe-Alkemade et al., 2016; Schut \& Van de Ven, 2011). Krabbe-Alkemade et al. (2016) found that the introduction of price competition led to lower total hospital costs.

The effect of the introduction of price competition on hospital quality has not previously been estimated. A few studies look at the relationship between price and quality variation or between hospital concentration and quality after prices were liberalized. Heijink et al. (2013) find only limited variation in hospital quality and no relationship between contract prices and quality for cataract care. Croes et al. (2017) find a negative relationship between hospital market share and quality scores for two of the three diagnostic groups studied. Bijlsma et al. (2013) find that hospital concentration is associated with various process indicators, but both positive and negative relationships are found and there is no relationship between hospital concentration and any of a number of outcome indicators examined. None of these studies have a design capable of identifying a causal effect of competition on quality.

\section{Data and measures}

\section{A. Sources and sample}

We use comprehensive, hospital-level data from the National Medical Registry on patient discharges from all Dutch hospitals between 2001 and 2007. For each discharge, we observe the patient's gender, age, zip code, primary/secondary/tertiary diagnoses (ICD-9CM), admission period, admission hospital and procedures. Procedures are classified according to a Dutch method based on (and for the procedures examined equivalent to) the International Classification of Procedures in Medicine (WHO-FIC, 2017). We restrict attention to patients discharged after a non-acute hip replacement (see below for details of the selection criteria). We construct a hospital-level panel which includes information on quality of care and patient case mix, and supplement this with an index of socio-economic status that is averaged over all the non-acute hip replacement patients of a hospital in a given year. This index is constructed by the Netherlands Institute for Social Research from the education, income and labor market status of residents of a zip code area (SCP, 2017). 
In total, our panel consists of 89 hospitals observed from 2003 to 2007, yielding 445 hospital-year observations. These hospitals admitted a total of 29,923 non-acute hip replacement patients per year, on average (SD: 1,525).

\section{B. Quality measures}

We use the unplanned 90-day readmission rate following non-acute hip replacement as our main quality indicator. This is preferred to the post hip replacement mortality rate because the latter was very low in the Netherlands in the period studied ${ }^{7}$. Higher (unplanned) readmission rates have been shown to be related to suboptimal quality of treatment both generally (e.g. Rosen et al., 2013; Mokhtar et al., 2012) and following hip replacement (e.g. Clement et al., 2013; Avram et al., 2014; Saucedo et al., 2014; Kurtz et al., 2016). Because planned readmissions (e.g. for a scheduled procedure) are not generally a signal of quality of care, we restrict attention to unplanned readmissions. All unplanned readmissions are attributed to the original treatment hospital. Unplanned readmissions following joint replacement are determined, in part, by the quality and safety of the initial hospital stay, transitional care services and post discharge support (Friebel et al., 2017). Widespread belief that readmissions are indicative of poor quality treatment is reflected in the fact that financial penalties for excess readmissions (including for hip replacements) have been imposed on hospitals in both the US and the UK since 2012 (Joynt \& Jha, 2012). Consistent with this, in our data, four of the top five reasons (identified from diagnostic codes) for hip replacement patients to be readmitted within 90-days are related to complications, infections or inflammatory reactions due to prosthetic implants. There is no consensus on whether a 90-day or 30-day follow-up window to define orthopedic readmissions provides the better indicator of quality (Ramkumar et al., 2015). Since the two are highly correlated for hip replacements in our data $(r(81)=.84$, $p<0.01$ in 2003 and $r(61)=.87, p<0.01$ in 2007), it should make little difference which is used. As for 90-day readmissions, complications are the main reason to be readmitted within 30days. We examine robustness of the estimates to using 30-day readmissions. Information on hip replacement readmission rates is not in the public domain or available to health insurers in the Netherlands, and so this indicator is unlikely to have been subject to manipulation by hospitals.

Sample inclusion and exclusion criteria were based on those defined in the technical specifications of the US Agency for Healthcare Research and Quality (AHRQ) Inpatient

\footnotetext{
${ }^{7}$ Using the Causes of Death Register provided by Dutch Hospital Data and Statistics Netherlands, we calculate a within hospital mortality rate of 0.23 percent and a 30-day mortality rate of 0.29 percent following non-acute hip replacement in the period 2003-2007. 
Quality Indicator \#14 (AHRQ QI Version 5.0; IQI \#14), which measures the hip replacement mortality rate. The population includes discharged patients aged 18 or older with any procedure code that indicates partial or full hip replacement and any diagnosis code that indicates osteoarthrosis of the pelvic region or thigh ${ }^{8}$. There were 79,140 such cases between 2003 and 2007. To exclude acute cases, we drop those with any listed diagnosis codes indicating hip fracture and those with codes indicating pregnancy, childbirth or puerperium. We also exclude those who transfer to another hospital because it is impossible to determine whether readmission in such cases indicates sub-optimal quality of the treatment received in the first or the second hospital. Cases with missing information on discharge address, gender, age, year or principal diagnosis $(\mathrm{n}=405)$ are also dropped, as are patients who died in the hospital $(n=183)^{9}$. After imposing all these exclusion restrictions, we are left with 70,273 discharges following non-acute hip replacement between 2003 and 2007. Of these, 8.2 percent were readmitted to a hospital within 90 days for any reason that was not planned.

\section{Measures of hospital market structure}

We measure concentration at the hospital level using the Herfindahl-Hirschman Index (HHI) based on the number of hospital beds ${ }^{10}: H H I_{h}=\sum_{i=1}^{N_{h}} m_{i}^{2}$, where $m_{i}$ is the percent market share of hospital $i$ that lies within a fixed radius of hospital $h$ and $N_{h}$ is the total number of hospitals in that market. Some hospitals have multiple locations that do not all lie within the same market defined by distance ${ }^{11}$. Online Appendix 2 explains how we calculate the HHI in these cases. For our baseline analysis, we use a 30 kilometers (by road) fixed radius because patients travel, on average, for 20 minutes to get to the hospital of their choice (Beukers et al., 2014; Varkevisser et al., 2012; Varkevisser et al., 2010) and most Dutch hospitals provide hip replacements (Roos et al., 2017). But since variation around the mean travel time is high (Beukers et al., 2014; Varkevisser et al., 2012; Varkevisser et al., 2010), we examine sensitivity to fixing the radius at 20,40 and 50 kilometers to define the market. Because providers are anonymized in the data to protect confidentiality, we cannot use the continuous measure of HHI once the hospital data are linked with patient-level data. The HHI of each hospital was therefore constructed in a database not containing patient-level data. Next, an indicator of whether the HHI is under 2500 was derived and this was then linked to the

\footnotetext{
${ }^{8}$ See Online Appendix 1 for the relevant procedure codes and ICD-9CM diagnosis codes.

${ }^{9}$ Given the very low within hospital mortality rate following non-acute hip replacement, any selection bias arising from excluding those who die is likely to have a negligible impact on the estimates (Fischer et al., 2014; Laudicella et al., 2013).

${ }^{10}$ The information on the number of beds per hospital location per year was assembled using several datasets that are/were partly publically available (Bartels, 2001; 2002; Prismant, 2003; 2004; 2005; 2006; CIBG, 2008; 2009; CBS, 2010; RIVM, 2006; 2008; 2009).

${ }^{11}$ Of the 103 hospitals, 5 had more than one location within the period that we study.
} 
patient-level dataset using the hospital identifier by Statistics Netherlands. Choice of the 2500 threshold is based on the convention in antitrust regulation that considers hospitals with an HHI at or above that value to be part of a highly concentrated market (e.g. FTC merger guidelines, 2010). It is assumed that these hospitals would be exposed to less price competition after 2005 when free negotiation of prices was allowed for hip replacements than hospitals operating in less concentrated markets.

\section{Empirical strategy}

We identify the effect of price competition on quality by comparing the change after price liberalization in hip replacement readmission rates of hospitals operating in less concentrated markets with the before-and-after difference in the readmission rates of hospitals in highly concentrated markets. Hospitals with an HHI below 2500 form our treatment group, while those with a HHI of at least 2500 belong to the comparison group. Comparing changes in hip replacement readmission rates of these two groups does not identify the impact of introducing price competition per se, but identifies the effect of greater exposure to price competition provided the two groups would have followed parallel trends in readmission rates if price setting had not been liberalized.

Only hospitals with a HHI either always below 2500 or always above 2500 during the period of analysis are used. Hence, no hospital can switch from the treatment group to the comparison group or vice versa, and the composition of each group is held constant by construction. Sixteen hospitals out of a total of 103 are excluded because they fail to meet this criterion. This is mainly because of merger activity ${ }^{12}$.

To avoid contamination from earlier and later policy changes ${ }^{13}$, we focus on a relatively narrow time window around the implementation of price liberalization. We use data from 2003 and 2004 to capture the period before price liberalization and data from 2006 and 2007 for the post-reform period. We exclude data from 2005 as the policy was implemented on February 1 of that year.

We estimate the following fixed effects model by least squares:

$$
R R_{h t}=\alpha+\delta 1\left(H H I_{h}<2500\right) \times \text { POST }_{t}+\boldsymbol{X}_{h t} \boldsymbol{\mu}+u_{h}+\lambda_{t}+\varepsilon_{h t}
$$

\footnotetext{
${ }^{12}$ Two other hospitals had to be excluded because the number of hip replacement cases was too low in the post-reform period.

${ }^{13}$ In 2008, the Health Care Inspectorate set up a program to develop reliable, comparable and valid quality information, free pricing negotiations were extended to about 20 per cent of hospitals' revenues, specialists' payments changed and entry to the hospital market became easier because of the abolishment of government approval over hospital construction. All of these changes potentially affect the relationship between market concentration and quality of care. Hence, we are limited to using data until 2007 to examine the impact of price liberalization for hip replacements introduced in 2005 .
} 
where $R R_{h t}$ is the unplanned 90-day readmission rate (percent) for non-acute hip replacements at hospital $h$ in year $t, 10$ is the indicator function, $\mathrm{POST}_{\mathrm{t}}$ is a binary indicator equal to 1 for the post-reform period (2006 \& 2007), $\boldsymbol{X}_{h t}$ is a vector of hospital characteristics that vary over time but are plausibly not affected by the introduction of price liberalization, $u_{h}$ is a hospital fixed effect, $\lambda_{t}$ is a year effect and $\varepsilon_{h t}$ is a random error term. The covariates consist of the Charlson index of comorbidity (Quan et al., 2011; 2005) averaged over a hospital's non-acute hip replacement patients in a year, the percentage of these patients aged 65+, 40-60 and 18-39 years, the percentage female, the percentage discharged to a skilled nursing facility ${ }^{14}$, and the mean zip code-specific socioeconomic score of the patients. These indicators of case mix are included to increase efficiency and to allow for any change in the composition of hip replacement patients that differs between hospitals in less and more concentration markets without being caused by the differential effect of price liberalization. We argue at the end of this section that there is little or no reason to expect the reform to have caused hip replacement patients to select different hospitals or hospitals to have selected different patients.

Table 1 presents means of the covariates before and after the reform for the treatment and comparison groups. Prior to the reform, there are some significant differences in the characteristics of the patients across the two groups. But the differences are rather small. Significance reflects the large sample size. The treatment group has a slightly higher proportion of females, its patients are older by about 1 year and they have higher socioeconomic status and propensity to be admitted to a skilled nursing facility after discharge, on average. There are no pre-reform differences in comorbidity measured by the Charlson. The characteristics of the patients change relatively little between the two periods for both groups. None of the difference-in-differences of these characteristics are significantly different from zero, indicating that there was no differential change in the composition of the groups with respect to these observables.

If in the absence of price liberalization in 2005 the average readmission rate of hospitals in less concentrated markets would have changed in 2006-07 by as much as the change that actually occurred in the hospitals operating in the more concentrated markets, then the

\footnotetext{
${ }^{14}$ Our dataset indicates whether the patient went home, to another general hospital, to another academic hospital, to a nursing home or to another healthcare organization after discharge. According to a recent (and unpublished) study by Statistics Netherlands, the majority of patients that is included in the 'another healthcare organization' category is transferred to a nursing home facility (approximately 70 percent). In this paper, we assigned every patient that is included in the 'nursing home' and 'other healthcare organization' categories to a 'transferred to a skilled nursing home facility' variable. This measure is obviously not entirely correct but given that we are not able to distinguish specific organizations within the 'another healthcare organization' group, this was the best we could do.
} 
parameter $\delta$ in (1) corresponds to the average effect of the increased exposure to price competition on the readmission rate among the hospitals in the less concentrated markets.

\section{TABLE 1 - MEANS OF COVARIATES BY PERIOD AND TREATMENT GROUP}

\begin{tabular}{|c|c|c|c|c|}
\hline Patients' characteristics & & Treatment group & Comparison group & Difference (-in- \\
\hline \multirow[t]{3}{*}{ Proportion female } & Pre-reform (2003-04) & $\begin{array}{c}0.72 \\
{[0.05]}\end{array}$ & $\begin{array}{c}0.69 \\
{[0.05]}\end{array}$ & $\begin{array}{c}0.03 * * * \\
(0.01)\end{array}$ \\
\hline & Post-reform (2006-07) & $\begin{array}{c}0.69 \\
{[0.06]}\end{array}$ & $\begin{array}{c}0.67 \\
{[0.06]}\end{array}$ & \\
\hline & Change & $\begin{array}{c}0.03^{* * *} \\
(0.01)\end{array}$ & $\begin{array}{c}0.01 \\
(0.01)\end{array}$ & $\begin{array}{l}-0.01 \\
(0.01)\end{array}$ \\
\hline \multirow[t]{3}{*}{ Mean age } & Pre-reform (2003-04) & $\begin{array}{l}70.97 \\
{[2.42]}\end{array}$ & $\begin{array}{l}69.96 \\
{[2.22]}\end{array}$ & $\begin{array}{c}1.01 * * * \\
(0.37)\end{array}$ \\
\hline & Post-reform (2006-07) & $\begin{array}{l}70.98 \\
{[2.69]}\end{array}$ & $\begin{array}{l}70.26 \\
{[1.84]}\end{array}$ & \\
\hline & Change & $\begin{array}{l}-0.01 \\
(0.45)\end{array}$ & $\begin{array}{l}-0.31 \\
(0.35)\end{array}$ & $\begin{array}{l}-0.29 \\
(0.57)\end{array}$ \\
\hline \multirow[t]{3}{*}{$\begin{array}{l}\text { Mean socioeconomic } \\
\text { score }\end{array}$} & Pre-reform (2003-04) & $\begin{array}{c}7.46 \\
{[0.48]}\end{array}$ & $\begin{array}{c}6.88 \\
{[0.52]}\end{array}$ & $\begin{array}{c}0.58^{* * * *} \\
(0.08)\end{array}$ \\
\hline & Post-reform (2006-07) & $\begin{array}{c}7.48 \\
{[0.49]}\end{array}$ & $\begin{array}{c}6.92 \\
{[0.55]}\end{array}$ & \\
\hline & Change & $\begin{array}{l}-0.01 \\
(0.08)\end{array}$ & $\begin{array}{l}-0.04 \\
(0.09)\end{array}$ & $\begin{array}{l}-0.03 \\
(0.12)\end{array}$ \\
\hline \multirow[t]{3}{*}{$\begin{array}{l}\text { Mean Charlson Score } \\
\text { (comorbidity) }\end{array}$} & Pre-reform (2003-04) & $\begin{array}{c}0.0024 \\
{[0.0089]}\end{array}$ & $\begin{array}{c}0.0015 \\
{[0.0045]}\end{array}$ & $\begin{array}{c}0.0009 \\
(0.0011)\end{array}$ \\
\hline & Post-reform (2006-07) & $\begin{array}{c}0.0018 \\
{[0.0048]}\end{array}$ & $\begin{array}{c}0.0008 \\
{[0.0022]}\end{array}$ & \\
\hline & Change & $\begin{array}{c}0.0006 \\
(0.0012)\end{array}$ & $\begin{array}{c}0.0007 \\
(0.0006)\end{array}$ & $\begin{array}{c}0.00 \\
(0.00)\end{array}$ \\
\hline \multirow[t]{3}{*}{$\begin{array}{l}\text { Proportion discharged to } \\
\text { skilled nursing facility }\end{array}$} & Pre-reform (2003-04) & $\begin{array}{c}0.08 \\
{[0.10]}\end{array}$ & $\begin{array}{c}0.05 \\
{[0.06]}\end{array}$ & $\begin{array}{l}0.03^{* *} \\
(0.01)\end{array}$ \\
\hline & Post-reform (2006-07) & $\begin{array}{c}0.08 \\
{[0.13]}\end{array}$ & $\begin{array}{c}0.05 \\
{[0.01]}\end{array}$ & \\
\hline & Change & $\begin{array}{l}-0.00 \\
(0.02)\end{array}$ & $\begin{array}{l}-0.00 \\
(0.01)\end{array}$ & $\begin{array}{l}-0.00 \\
(0.02)\end{array}$ \\
\hline Number of hospitals & & 72 & 72 & 72 \\
\hline Number of patients & & 25,197 & 30,281 & 55,478 \\
\hline
\end{tabular}

Notes: Pre-/post-reform cell entries are obtained by first computing the mean across all non-acute hip replacement patients discharged from each hospital and then taking the simple average of these means across all hospitals within a group and period. Figures in square brackets are standard deviations across hospitals. Figures in parentheses are standard errors of the estimated change in the mean. Hospitals and patients are selected using the criteria described in section IVB. The socioeconomic score is increasing in socioeconomic status and ranges from 0 to 10. The Charlson score (Quan et al. 2011) ranges from 0 to 9 , with higher being more severe.

*** Significant at the 1 percent level. ** Significant at the 5 percent level.

Figure 1 supports the plausibility of the common trends identification assumption. Even going back to 2001, two years before the start of the pre-reform period that we use for identification of the effect, the trend in the readmission rate, and indeed its level, prior to the 2005 reform is very similar for hospitals operating in more and less concentrated markets. Estimation of a model similar to (1) using data from 2001 to 2004 and allowing the year 
effects to differ between hospitals located in more and less concentrated markets reveals no evidence of differential trends in the period immediately preceding the reform (Online Appendix 3; table 1; column (i)).

FIGURE 1. 90-DAY READMISSION RATE AFTER HIP REPLACEMENT PER YEAR \& PER HHI GROUP (RADIUS $30 \mathrm{KM}$ )

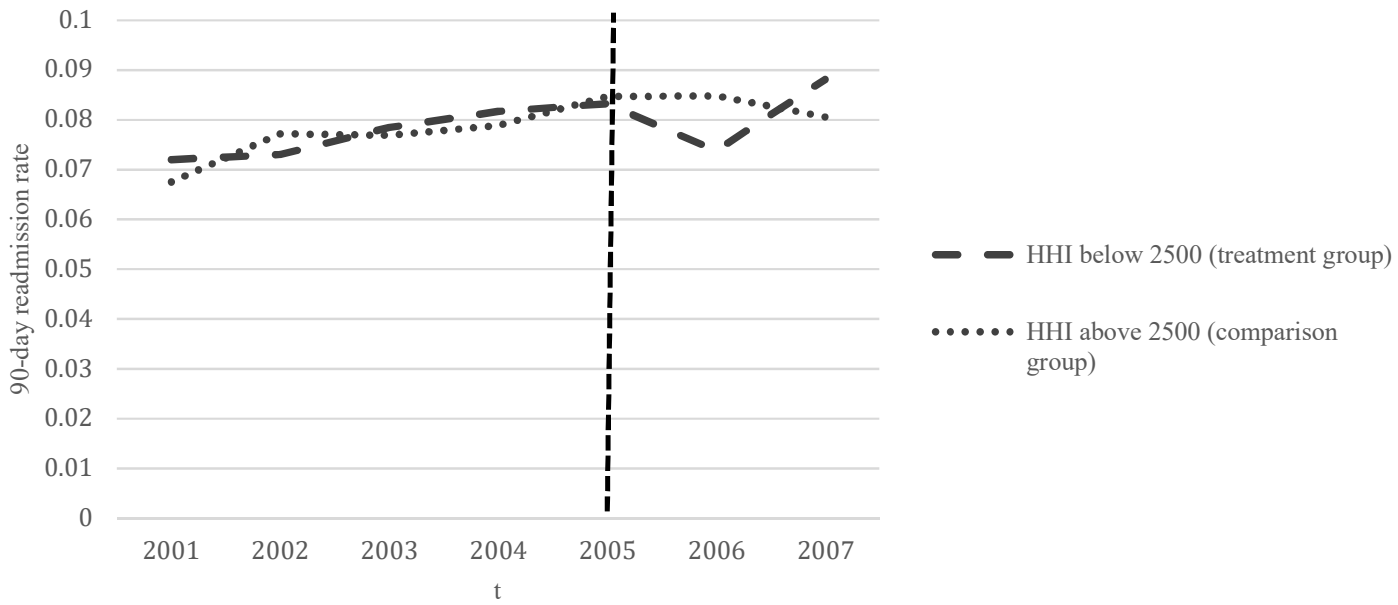

A gap opens up in the readmission rates in 2006 immediately after the liberalization of price setting (Figure 1). The readmission rate falls in the less concentrated markets but not in the more concentrated markets. If the common trends assumption holds, this would suggest that hospitals that were more exposed to price competition raised the quality of the care they delivered. However, the divergence is not sustained. In 2007, the readmission rate rises again in less concentrated markets, while remaining constant for hospitals largely shielded from competitive pressures. Over the two-year post-reform period, the graph suggests that price liberalization did not consistently lower or raise the quality of hip replacements. Motivated by the figure and because hospitals and insurers may not have fully adjusted to the new contracting conditions immediately after prices became freely negotiable, we estimate a second model that allows the treatment effect to differ in the two post-reform years:

$R R_{h t}=\alpha+\sum_{k=6,7} \delta_{k} 1\left(H H I_{h}<2500\right) \times Y E A R 0 k_{t}+\boldsymbol{X}_{h t} \boldsymbol{\mu}+u_{h}+\lambda_{t}+\varepsilon_{h t}$

where YEAR06 $=1($ YEAR07 $=1)$ if the year is $2006(2007)$. Under the same common trends assumption, $\delta_{6}$ gives the average effect of increased exposure to price competition in 2006 and $\delta_{7}$ gives the equivalent effect in 2007.

Market concentration is generally considered to be potentially endogenous because performance may feed back into structure and unobservable attributes may influence both quality and patients' choice of hospital (Evans et al., 1993). In this study, both the empirical strategy and the institutional context eliminate or, at least greatly minimize, the threat to 
identification from endogeneities of both types. Hospital fixed effects deal with any time invariant correlated unobservables. Further, we avoid using any time varying information on market concentration. Each hospital is categorized into one of two groups according to whether its HHI starts and remains either below 2500 or above 2500 . Since barely any quality information was available around the time of the reform, it is unlikely that any change in quality would affect patient flows. But even if there was a feedback from quality to market concentration, any such endogenously induced variation in the HHI is not used in the estimation, and so cannot cause bias. Hospitals that cross the HHI threshold of 2500, possibly arising from a change in performance that either attracts or deters patients, are dropped from the sample. Quality-induced changes in market concentration of this magnitude, if they exist, are also not used in the estimation. Since we do not identify from time variation in HHI, there would be no advantage from calculating the $\mathrm{HHI}$ on the basis of predicted, rather than actual, patient flows, as some others have done (Kessler \& McClellan, 2000; Cooper et al., 2011; Gaynor et al., 2013).

We deliberately choose an elective procedure to measure quality in order to obtain evidence on the effect of competition on a treatment that is likely to exhibit much greater demand elasticity with respect to quality than is the case with acute treatments (e.g. for AMI), the demand for which is likely dominated by proximity. Hitherto, the literature has made the opposite choice (see e.g. Cooper et al., 2011; Gaynor et al., 2013). Lack of direct relevance of competition to the acute procedure used to measure quality has been accepted in order to obtain a measure that is less vulnerable to endogeneity arising from patient selection of the provider. There are three reasons why our study is less vulnerable to this selection bias. First, we eliminate correlated, time invariant unobservable differences in patient composition across hospitals with fixed effects. Only if the reform were to change unobservable patient characteristics differentially across the treatment and comparison groups would there be any potential bias. Second, as previously mentioned, patients and insurers lacked information on hospital quality, including readmission rates for hip replacements, before and after the reform. There was limited scope for selection on quality. Third, in contrast to the UK healthcare market reforms that have been the subject of many previous studies ${ }^{15}$, price liberalization in the Netherlands did not change opportunities for patient choice. Patients and health insurers had free choice of provider before and after the reform. In addition to these conceptual

\footnotetext{
15 These studies either use rich data or intruments to deal with time varying patient selection. Skellern (2017) controls for risk-adjusted Patient Reported Outcome Measures (PROMs), while Gaynor et al. (2013); Cooper et al. (2011) and Moscelli et al. (2016) instrument hospital choice using GP/patient-hospital distances. Cooper et al. (2011) do not reject exogeneity of market structure and Moscelli et al. (2016) find that instrumenting has very little impact on the estimates, relative to controlling for a rich set of patient covariates.
} 
arguments, the comparisons of patient characteristics in Table 1 give empirical grounds to believe that identification is unlikely to be invalidated by endogenous patient selection. None of the observable indicators of case mix changed differently in the treatment group than in the comparison group. In fact, there was very little change at all in these characteristics. If observables changed little and, if at all, comparably, there is little reason to believe that unobservables changed markedly differentially across the groups.

Hospital initiated selection of patients is potentially of greater concern in the context of this study. Price liberalization could potentially give hospitals operating in competitive markets the incentive to drive down costs and simultaneously cherry pick more straightforward cases so that tighter budgets would not impinge on quality. However, because we identify from comparison across hospitals categorized by broad ranges of HHI, any cherry picking could bias our results only if it resulted in patients being shunted long distances. More likely is that a hospital would refer a patient who is at greater risk of readmission to a neighboring hospital, which is likely to be in the same treatment or comparison group. So, while the case mix of individual hospitals may change due to patient selection in response to the reform, it is rather unlikely that this would change the composition of the groups. The comparisons of observable patient characteristics given in Table 1 again support this.

\section{Results}

\section{A. Main estimates}

Prior to the reform, there was no significant difference in either the 90-day or the 30-day readmission rate between the treatment (high competitive pressure) group and the comparison (low competitive pressure) group (Table 2). Post reform, the readmission rate remained constant in the treatment group and increased (10\% significance) in the comparison group. Consequently, the simple difference-in-differences is negative, which would indicate that increased competition led to lower readmission rates (i.e. higher clinical quality), but it is not significantly different from zero.

The conditional difference-in-differences (DID) estimate given in the first column of the top panel of Table 3 is essentially the same as the simple DID estimate in magnitude and lack of significance. The similarity provides a further indication that there is likely to be little bias from correlated time varying unobservables. These results suggest there was no effect of greater exposure to price competition on 90-day readmission rates. Consistent with what was observed in Figure 1, the conditional DID estimates in the first column of the second panel of 
Table 3 suggest that increased price competition reduced the 90 -day readmission rate by 1 percentage point in the first year (2006) after the reform but had no effect in the second year (2007). As is apparent from Figure 1, the significant effect in 2006 is driven by a fall in the readmission rate of the hospitals exposed most to competition while the readmission rate of hospitals that are dominant in their markets did not change.

TABLE 2 - UNPLANNED 90-DAY AND 30-DAY HIP REPLACEMENT READMISSION RATES BY PERIOD AND TREATMENT GROUP

\begin{tabular}{|c|c|c|c|c|}
\hline Outcome & & $\begin{array}{l}\text { Treatment group } \\
(H H I<2500) \\
\text { (1) }\end{array}$ & $\begin{array}{l}\text { Comparison group } \\
\text { (HHI }>2500) \\
\text { (2) }\end{array}$ & $\begin{array}{l}\text { Difference (-in- } \\
\text { difference) } \\
\text { (1)-(2) }\end{array}$ \\
\hline \multirow[t]{3}{*}{ 90-day readmission rate } & Pre-reform & $\begin{array}{c}0.0825 \\
(0.0037)\end{array}$ & $\begin{array}{c}0.0788 \\
(0.0027)\end{array}$ & $\begin{array}{c}0.0037 \\
(0.0045)\end{array}$ \\
\hline & Post-reform & $\begin{array}{c}0.0814 \\
(0.0041)\end{array}$ & $\begin{array}{c}0.0855 \\
(0.0032)\end{array}$ & \\
\hline & Change (Post-Pre) & $\begin{array}{c}-0.0011 \\
(0.0055)\end{array}$ & $\begin{array}{c}0.0067 \\
(0.0042)\end{array}$ & $\begin{array}{c}-0.0077 \\
(0.0069)\end{array}$ \\
\hline \multirow[t]{3}{*}{ 30-day readmission rate } & Pre-reform & $\begin{array}{c}0.0480 \\
(0.0027)\end{array}$ & $\begin{array}{c}0.0434 \\
(0.0020)\end{array}$ & $\begin{array}{c}0.0046 \\
(0.0034)\end{array}$ \\
\hline & Post-reform & $\begin{array}{c}0.0492 \\
(0.0031)\end{array}$ & $\begin{array}{c}0.0486 \\
(0.0022)\end{array}$ & \\
\hline & Change (Post-Pre) & $\begin{array}{c}0.0012 \\
(0.0041)\end{array}$ & $\begin{array}{l}0.0052^{*} \\
(0.0030)\end{array}$ & $\begin{array}{c}-0.0040 \\
(0.0051)\end{array}$ \\
\hline Number of hospitals & & 36 & 36 & 72 \\
\hline Number of patients & & 25,197 & 30,281 & 55,478 \\
\hline
\end{tabular}

Notes: Table gives the simple mean readmission rate averaged over all hospitals in the treatment $(\mathrm{HHI}<2500)$ group and the comparison (HHI 2500) group. Robust standard errors in parentheses. Hospitals and patients selected by criteria described in section IVB.

* Significant at the 10 percent level.

\section{B. Robustness}

\section{$\underline{\text { Market definition }}$}

The main estimates are generated on the basis of HHIs calculated with a radius of $30 \mathrm{~km}$ used to define the boundary of the market around a hospital. To check robustness, we recalculate the HHI using a radius of 20,40 and $50 \mathrm{~km}$ to define a market, recategorize hospitals into the treatment and comparisons groups on the basis of the revised index and then re-estimate models (1) and (2) in each case. Estimates are given in the appropriately labelled columns of Table 3. With a radius of $30 \mathrm{~km}$, hospitals are evenly split between the treatment and comparison groups. As the radius is widened, more hospitals get put into the treatment group because the HHI decreases as the area that defines the market increases.

Irrespective of the radius used, the treatment effect averaged over the two years of the postreform period is insignificant. When the radius is increased, the year specific estimates obtained from model (2) continue to indicate that exposure to more intensive price 
competition significantly reduced the readmission rate by a similar magnitude in 2006 . When the radius is reduced, the estimate of this effect falls in magnitude and loses significance. This may be because more hospitals are then in the comparison group. At least some of the hospitals that have a HHI below 2500 using a $30 \mathrm{~km}$ radius but above 2500 with a radius of $20 \mathrm{~km}$ may, in reality, be exposed to competitive pressure and so respond to the price liberalization similarly to those that remain in the treatment group irrespective of the radius used. This will reduce the DID between the groups. There is no significant effect in 2007 irrespective of the geographic radius used to define the market. In general, irrespective of the radius used to define a hospital market, there is no clear evidence that increased price competition consistently impacted on the readmission rate.

\section{TABLE 3 - ESTIMATED EFFECTS OF PRICE COMPETITION ON READMISSION RATES AFTER HIP REPLACEMENT}

\begin{tabular}{|c|c|c|c|c|c|}
\hline & $\begin{array}{l}\text { 90-day readmission } \\
\text { (radius 30) }\end{array}$ & $\begin{array}{l}\text { 90-day readmission } \\
\text { (radius 20) }\end{array}$ & $\begin{array}{l}\text { 90-day readmission } \\
\text { (radius } 40 \text { ) }\end{array}$ & $\begin{array}{l}\text { 90-day readmission } \\
\text { (radius 50) }\end{array}$ & $\begin{array}{l}\text { 30-day readmission } \\
\text { (radius } 30 \text { ) }\end{array}$ \\
\hline \multicolumn{6}{|l|}{ Model (1) } \\
\hline$\hat{\delta}$ & $\begin{array}{l}-0.0095 \\
(0.0066)\end{array}$ & $\begin{array}{l}-0.0041 \\
(0.0067)\end{array}$ & $\begin{array}{l}-0.0094 \\
(0.0061)\end{array}$ & $\begin{array}{l}-0.0084 \\
(0.0075)\end{array}$ & $\begin{array}{l}-0.0042 \\
(0.0048)\end{array}$ \\
\hline $\mathrm{R}^{2}$ & 0.55 & 0.58 & 0.58 & 0.58 & 0.55 \\
\hline \multicolumn{6}{|l|}{ Model (2) } \\
\hline$\hat{\delta}_{6}(2006)$ & $\begin{array}{c}-0.0189 * * \\
(0.0074)\end{array}$ & $\begin{array}{l}-0.0114 \\
(0.0079)\end{array}$ & $\begin{array}{c}-0.0170^{* *} \\
(0.0076)\end{array}$ & $\begin{array}{c}-0.0179 * * \\
(0.0091)\end{array}$ & $\begin{array}{l}-0.0084 \\
(0.0056)\end{array}$ \\
\hline$\hat{\delta}_{7}(2007)$ & $\begin{array}{l}-0.0000 \\
(0.0082)\end{array}$ & $\begin{array}{c}0.0040 \\
(0.0083)\end{array}$ & $\begin{array}{l}-0.0011 \\
(0.0071)\end{array}$ & $\begin{array}{c}0.0024 \\
(0.0085)\end{array}$ & $\begin{array}{c}0.0001 \\
(0.0059)\end{array}$ \\
\hline $\mathrm{R}^{2}$ & 0.56 & 0.59 & 0.58 & 0.59 & 0.55 \\
\hline $\mathrm{N}$ treatment hospitals & 36 & 19 & 44 & 52 & 36 \\
\hline $\begin{array}{l}\mathrm{N} \text { comparison } \\
\text { hospitals }\end{array}$ & 36 & 44 & 20 & 12 & 36 \\
\hline $\mathrm{N}$ hospitals $\times$ years & 287 & 247 & 249 & 245 & 287 \\
\hline $\mathrm{N}$ patients & 55,478 & 46,823 & 45,472 & 46,696 & 55,478 \\
\hline $\mathrm{N}$ readmitted patients & 5,706 & 4,788 & 4,705 & 4,787 & 1,290 \\
\hline
\end{tabular}

Notes: Top panel gives OLS estimates of $\delta$ from regression (1). Second panel gives OLS estimates of $\delta_{6}$ and $\delta_{7}$ from regression (2). All estimates obtained from regressions containing hospital and year fixed effects and covariates identified in Table 1. Full estimates in Online Appendix 3; Tables A2 and A3. Robust standard errors in parentheses. Hospitals and patients selected by criteria described in section IVB. Radius $\mathrm{X}$ indicates that the estimates are based on treatment/comparison groups formed on the basis of a HHI calculated with a radius of X km defining the boundary of a market. The sample size falls as the radius is reduced because more hospitals cross the HHI threshold of 2500 used to define the treatment/comparison groups during the estimation period.

** Significant at the 5 percent level.* Significant at the 10 percent level.

\section{$\underline{\text { 30-day readmission rate }}$}

Since arguments and evidence supporting the 90-day readmission rate as a better indicator of quality of care than the 30-day rate are lacking, we check robustness to using the shorter period. Pre-reform trends in 30-day readmission rates are reasonably parallel between the treatment and comparison groups, although there is a slight dip for the comparison group only in 2003 (see Figure 2). The hypothesis that year effects in the 30-day readmission rate are equal for the treatment and comparison group hospitals in the pre-treatment period is not 
rejected (Online Appendix 3, table A1; column (ii)), which lends plausibility to the parallel trends identification assumption for this outcome also.

The final column of Table 3 reveals that estimated effects on the 30-day readmission rate are generally smaller in magnitude than those on the 90-day rate. Over the full post-reform period, there continues to be no evidence that exposure to increased price competition consistently affected quality of care.

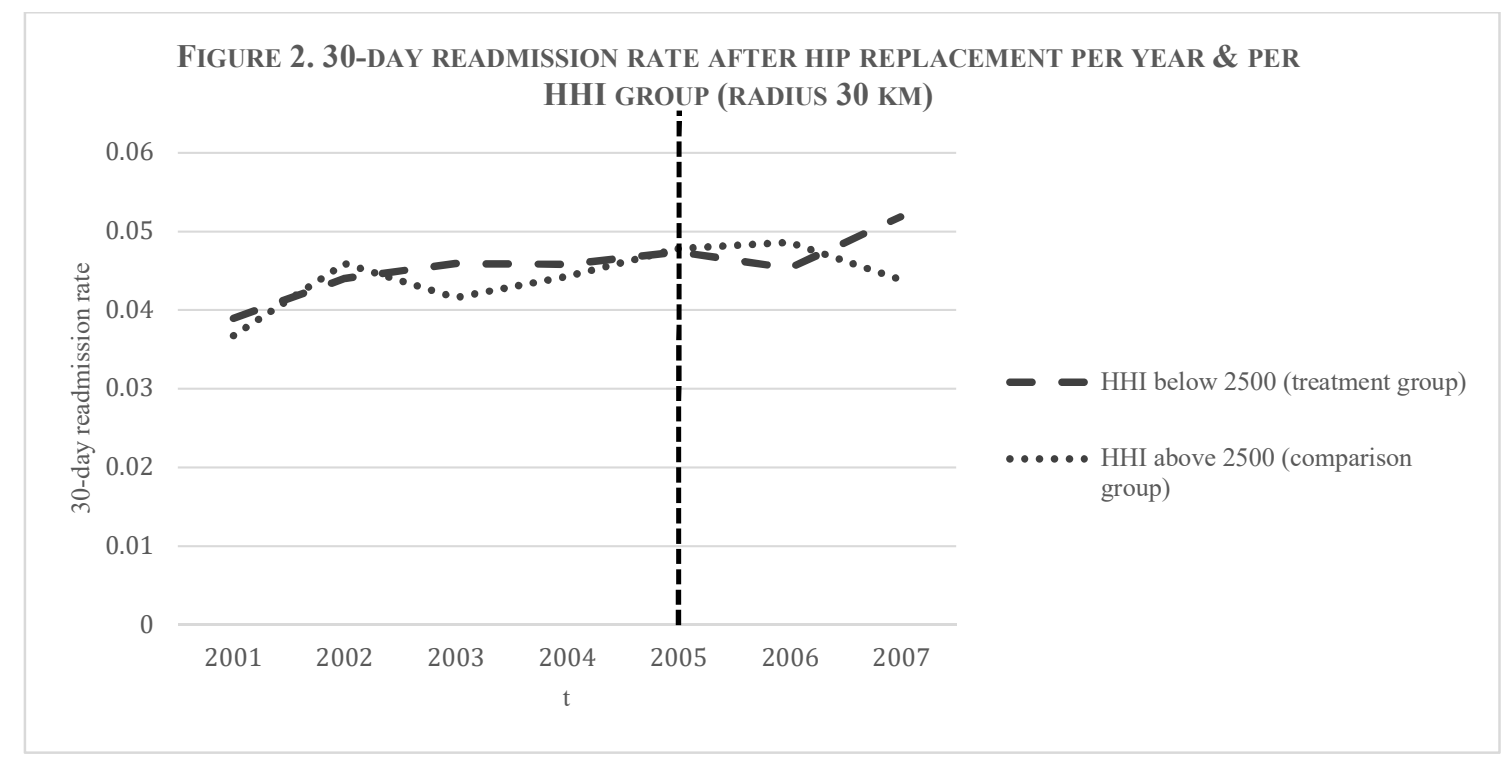

\section{Conclusion}

This is the first paper to credibly identify the effect of price competition on the quality of elective healthcare. When producers are free to compete on both price and quality, demand is potentially sensitive to both. However, when information on the latter is lacking or poor, organizations may increase profits by cutting both price and quality. This logic is one of the reasons why regulators have been leery of permitting price competition in healthcare markets. But in most countries, including the Netherlands, hospitals are not-for-profit organizations that may not be prepared to grasp a competitive advantage obtainable by cutting prices if this requires skimping on quality. Our findings are consistent with this behavior, although they certainly do not confirm it. Freedom to negotiate prices for a number of elective procedures did not result in lower quality care measured by readmission rates after hip replacements in the hospitals in the most competitive markets.

In the absence of meaningful quality information, even in a market dominated by not-forprofit organizations, one would expect contract negotiations between insurers and hospitals to focus on price. This focus may result in a (unintended) deterioration of quality. We find that 
exposure to increased price competition initially had a positive impact on quality. The hip replacement readmission rate fell in the most competitive hospital markets in the first year in which prices were liberalized. This may result from one side of the market's (hospital administrators') initial misapprehension of how the other side (insurers) would behave in the new contacting arrangements. For the first time, hospitals and insurers were negotiating contracts for hospital products (DRG equivalents) rather than agreeing on prospective budgets and related parameters, like hospital days. Hospitals may have understood that the insurers would be sensitive to both price and the quality of the products. Hospitals in more competitive markets might have been afraid that they would lose out if they did not improve their quality, as well as keeping prices down. When hospitals came to realize that bargaining primarily focused on price and not on quality, they may have decided to scale down initial quality improvement efforts. Of course, this is no more than supposition. It would have been interesting to extend the post-reform period of analysis to check whether, over time, a negative impact on quality did emerge. Unfortunately, this is not possible because of later reforms of the healthcare market that would confound identification of the effect of the 2005 reform (see footnote 13).

\section{REFERENCES}

AHRQ. 2015. AHRQ QIT Version 5.0, Inpatient Quality Indicators \#14, Technical Specifications, Hip Replacement Mortality Rate. Rockville: Agency of Healthcare Research and Quality.

Avram. V., D. Petruccelli, M. Winemaker \& J. de Beer. 2014. 'Total joint arthroplasty readmission rates and reasons for 30-day hospital readmission'. The Journal of Arthroplasty. 29:465-468.

Bartels. L.P. 2001. Instellingen van Intramurale Gezondheidszorg: basisgegevens per 1-1-2001. Utrecht: Prismant.

Bartels. L.P. 2002. Instellingen van Intramurale Gezondheidszorg: basisgegevens per 1-1-2002. Utrecht: Prismant.

Berta. P., G. Martini, F. Moscone \& G. Vittadini. 2016. 'The association between asymmetric information, hospital competition and quality of healthcare: evidence from Italy'. Journal of the Royal Statistical Society: Series A. 179(4):907-926.

Beukers. P.D.C., R.G.M. Kemp \& M. Varkevisser. 2014. 'Patient hospital choice for hip replacement: empirical evidence from the Netherlands'. European Journal of Health Economics. 15:927-936.

Bevan. G. \& M. Skellern. 2011. 'Does competition between hospitals improve clinical quality? A review of evidence from two eras of competition in the English NHS'. British Medical Journal. 343(7):6470-6470.

Bijlsma. M.J., P.W.C. Koning \& V. Shestalova. 2013. 'The Effect of Competition on Process and Outcome Quality of Hospital Care in the Netherlands'. De Economist. 161(2):121-155. 
Bloom. N., C. Propper, S. Seiler \& J. van Reenen. 2015. 'The Impact of Competition on Management Quality: Evidence from Public Hospitals'. Review of Economic Studies. 82:457-489.

CBS (Centraal Bureau voor de Statistiek). 2010. Bestand Adressen Nederlandse Ziekenhuizen op basis van RIVM Volksgezondheid Toekomst Verkenning. Den Haag: Centraal Bureau voor de Statistiek.

CIBG. 2008. Jaarverslagen Zorg. Den Haag: CIBG.

CIBG. 2009. Jaarverslagen Zorg. Den Haag: CIBG.

Clement. R.C., P.B. Derman, D.S. Graham, R.M. Speck, D.N. Flynn., L.S. Levin, L.A Fleisher. 2013. 'Risk factors, causes and the economic implications of unplanned readmissions following total hip arthroplasty'. The Journal of Arthroplasty. 28: 7-10.

Colla. C.H., J. Bynum, A. Austin \& J. Skinner. 2016. 'Hospital competition, quality and expenditures in the US Medicare population'. NBER Working papers No. 22826. Cambridge: National Bureau of Economic Research.

Cooper. Z., S. Gibbons, S. Jones \& A. McGuire. 2011. 'Does hospital competition save lives? Evidence from the English NHS patient choice reforms'. The Economic Journal. 121:F228-F260.

Croes. R.R., Y.J.F.M. Krabbe-Alkemade \& M.C. Mikkers. 2017. 'Competition and quality indicators in the health care sector: empirical evidence from the Dutch hospital sector'. The European Journal of Health Economics. 1-15. Doi:10.1007/s10198-016-0862-6.

Determann. D., M.S. Lambooij, E.W. de Bekker-Grob, A.P. Hayen, M.Varkevisser, F.T. Schut \& G.A. de Wit. 2016. 'What health plans do people prefer? The trade-off between premium and provider choice'. Social Science \& Medicine. 165:10-18.

Dorfman. R. \& P.O. Steiner. 1954. 'Optimal Advertising and Optimal Quality'. The American Economic Review. 44(5):826-836.

Dranove. D. \& M.A. Satterthwaite. 2000. The Industrial Organization of Health Care Markets. In: 'Handbook of Health Economics, Volume 1B'. (eds: A.J. Culyer \& J.P. Newhouse). Amsterdam \& Boston: Elsevier. 1093-1139.

Evans. W.N., L.M. Froeb \& G.J. Werden. 1993. 'Endogeneity in the concentration-price relationships: causes, consequences and cures'. The Journal of Industrial Economics. 4:431-438.

FTC (Federal Trade Commission). 2010. Horizontal Merger Guidelines. Washington: Federal Trade Commission.

Fischer. C., H.F. Lingsma, P.J. Marang-van de Mheen, D.S. Kringos, N.S. Klazinga \& E.W. Steyerberg. 2014. 'Is the readmission rate a valid quality indicator? A review of the evidence'. PLOS one. 9(11):1-9.

Friebel. R., K. Dharmarajan, H. Krumholz \& A. Steventon. 2017. 'Reductions in Readmission Rates are Associated with Modest Improvements in Patient-reported Health Gains following Hip and Knee Replacement in England'. Medical Care. 55(9):834-840.

Gaynor. M. 2006. 'What Do We Know About Competition and Quality in Health Care Markets?'. Foundations and Trends in Microeconomics. 2(6):1-40.

Gaynor. M., K. Ho \& R.J. Town. 2015. 'The industrial organization of health-care markets'. Journal of Economic Literature. 53(2):235-284.

Gaynor. M., R. Moreno-Serra \& C. Propper. 2013. 'Death by Market Power: Reform, Competition and Patient Outcomes in the National Health Service'. American Economic Journal: Economic Policy. 5(4):134-166.

Gaynor. M., C. Propper \& S. Seiler. 2016. 'Free to choose? Reform, Choice and Consideration Sets in the English National Health Service'. American Economic Review. 106(11):35213557. 
Gaynor. M. \& R.J. Town. 2012. Chapter 9. Competition in Health Care Markets. In: 'Handbook of Health Economics Volume 2'. (eds: McGuire. T., M.V. Pauly \& P. Pita Barros). Amsterdam: Elsevier North-Holland. 499-637.

Gobillon. L. \& C. Milcent. 2017. Competition and hospital quality: evidence from a French natural experiment. 'CEPR Discussion Papers 11773'.

Gowrisankaran. G., A. Nevo \& R.J. Town. 2015. 'Mergers when prices are negotiated: evidence from the hospital industry'. American Economic Review. 105(1):172-203.

Gowrisankaran. G. \& R.J. Town. 2003. 'Competition, Payers and Hospital Quality'. Health Services Research. 38(6):1403-1422.

Gravelle. H., G. Moscelli, R. Santos \& L. Siciliani. 2014. Patient choice and the effects of hospital market structure on mortality for AMI, hip fracture and stroke patients. 'CHE Research Paper 106'. York: Centre for Health Economics.

Halbersma. R.S., M.C. Mikkers., E. Motchenkova \& I. Seinen. 2010. 'Market structure and hospital-insurer bargaining in the Netherlands'. European Journal of Health Economics. 12(6):589-603.

Heijink. R., I. Mosca \& G. Westert. 2013. 'Effects of regulated competition on key outcomes of care: Cataract surgeries in the Netherlands'. Health Policy. 113(1-2):142-150.

Ho. K. 2009. 'Insurer-Provider Networks in the Medical Care Market'. American Economic Review. 99(1):393-430.

Joynt. K.E. \& A.K. Jha. 2012. 'Thirty-day readmissions: truth and consequences'. New England Journal of Medicine. 366:1366-1369.

Kessler. D. \& J.J. Geppert. 2005. 'The effects of competition on variation in the quality and cost of medical care'. Journal of Economics and Management Strategy. 14(3):575-589.

Kessler. D. \& M. McClellan. 2000. 'Is hospital competition socially wasteful?'. Quarterly Journal of Economics. 115 (2): 577-615.

Krabbe-Alkemade. Y., T. Groot \& M. Lindeboom. 2016. 'Competition in the Dutch hospital sector: an analysis of health care volume and cost'. European Journal of Health Economics. doi: 10.1007/s10198-016-0762-9.

Kurtz. S.M., E.C. Lau, K.L. Ong, E.M. Adler, F.R. Kolisek \& M.T. Manley. 2016. 'Hospital, patient, and clinical factors influence 30 - and 90-day readmission after primary total hip arthroplasty'. Doi: dx.doi.org/10.1016/j.arth.2016.03.041.

Laudicella. M., P. Li Donni \& P.C. Smith. 2013. 'Hospital readmission rates: Signal of failure or success?'. Journal of Health Economics. 32:909-921.

Meijer. S., R. Douven. \& B. van den Berg. 2010. 'Hoe beinvloedt gereguleerde concurrentie de Nederlandse ziekenhuismarkt?' [In Dutch]. TPEdigitaal. 4(1):39-49.

Mokhtar. S.A., A.A. El-Mahalli, S. Al-Mulla \& R. Al-Hussaini. 2012. 'Study of the relation between quality of inpatient care and early readmission for diabetic patients at a hospital in the eastern province of Saudi Arabia'. Eastern Mediterranean Health Journal. 18(5):474-479.

Moscelli. G., L. Siciliani, N. Gutacker \& H. Gravelle. 2016. 'Location, quality and choice of hospital: evidence from England 2002-2013'. Regional Science and Urban Economics. 60:112-124.

Moscelli. G., H.S.E. Gravelle \& L. Siciliani. 2016b. Market structure, patient choice and hospital quality for elective patients. 'CHE Research Paper 139'. York: Centre for Health Economics.

Mutter. R., P.S. Romano. \& H.S. Wong. 2011. 'The Effects of US Hospital Consolidations on Hospital Quality'. International Journal of the Economics of Business. 18(1):109-126.

NZa (Nederlandse Zorgautoriteit). 2009. Ziekenhuiszorg 2009 Tijd voor reguleringszekerheid. Utrecht: Nederlandse Zorgautoriteit.

Prismant. 2003. Enquête Jaarverslagen Zorg. Utrecht: Prismant. 
Prismant. 2004. Enquête Jaarverslagen Zorg. Utrecht: Prismant.

Prismant. 2005. Enquête Jaarverslagen Zorg. Utrecht: Prismant.

Prismant. 2006. Enquête Jaarverslagen Zorg. Utrecht: Prismant.

Propper. C., S. Burgess \& K. Green. 2004. 'Does competition between hospitals improve the quality of care? Hospital death rates and the NHS internal market'. Journal of Public Economics. 88:1247-1272.

Propper. C., S. Burgess. \& D. Gossage. 2008. 'Competition and quality: evidence from the NHS internal market 1991-99'. Economic Journal. 118:138-170.

Propper. C. 2011. 'Competition, Incentives and the English NHS'. Health Economics. 21:33-40.

Propper. C. 1996. 'Market structure and prices: the responses of hospitals in the UK National Health Service to competition'. Journal of Public Economics. 61: 307-335.

Quan. H., B. Li, C. Couris, K. Fushimi, P. Graham, P. Hider, J-M. Januel \& V. Sundararajan. 2011. 'Updating and Validating the Charlson Comorbidity Index and Score for Risk Adjustment in Hospital Discharge Abstracts Using Data from 6 Countries'. American Journal of Epidemiology. 173(6):676-682.

Quan. H., V. Sundararajan, P. Halfon, A. Fong, B. Burnand, J-C. Luthi, D. Saunders, C. Beck, T. Feasby \& W. Ghali. 2005. 'Coding Algorithms for Defining Comorbidities in ICD-9-CM and ICD-10 Administrative Data'. Medical Care. 43(11):1130-1139.

Ramkumar. P.N., C.T. Chu, J.D. Harris, A. Athiviraham, M.A. Harrington, D.L. White, D.H. Berger, A.D. Naik \& L.T. Li. 2015. 'Causes and Rates of Unplanned Readmissions after Elective Primary Total Joint Arthroplasty: A Systematic Review and Meta-Analysis'. The American Journal of Orthopedics. 44(9):397-405.

RIVM (Rijksinstituut voor Volksgezondheid en Milieu). 2006. Volksgezondheid Toekomst Verkenning: Nationale Atlas Volksgezondheid. Bilthoven: Rijksinstituut voor Volksgezondheid en Milieu.

RIVM (Rijksinstituut voor Volksgezondheid en Milieu). 2008. Volksgezondheid Toekomst Verkenning: Nationale Atlas Volksgezondheid. Bilthoven: Rijksinstituut voor Volksgezondheid en Milieu.

RIVM (Rijksinstituut voor Volksgezondheid en Milieu). 2009. Volksgezondheid Toekomst Verkenning: Nationale Atlas Volksgezondheid. Bilthoven: Rijksinstituut voor Volksgezondheid en Milieu.

Romano. P.S. \& D.J. Balan. 2011. 'A Retrospective Analysis of the Clinical Quality Effects of the Acquisition of Highland Park Hospital by Evanston Northwestern Healthcare'. International Journal of the Economics of Business. 18(1):45-64.

Roos. A.F., R.R. Croes, V. Shestalova, M. Varkevisser \& F.T. Schut. 2017. Price effects of a hospital merger: heterogeneity across health insurers, hospital products and hospital locations. "Working paper April 2017'. Rotterdam: Erasmus University Rotterdam.

Rosen. A.K., S. Loveland, M. Shin, M. Shwartz, A. Hanchate, Q. Chen et al. 2013. 'Examining the impact of the AHRQ Patient Safety Indicators (PSIs) on the Veterans Health Administration: the case of readmissions'. Medical Care. 51(1):37-44.

Ruwaard. S., R. Douven, J. Struijs \& J. Polder. 2014. 'Hoe kopen zorgverzekeraars in bij ziekenhuizen: een analyse van de contracten tussen verzekeraars en ziekenhuizen'. TPEdigitaal. 8(2):98-117.

Saucedo. J.M., G.S. Marecek, T.R. Wanke, J. Lee, S.D. Stulberg \& L. Puri. 2014. 'Understanding readmission after primary total hip and knee arthroplasty: who's at risk?'. The Journal of Arthroplasty. 29:256-260.

Sari. N. 2002. 'Do competition and managed care improve quality?'. Health Economics. 11:571584. 
Schut. F.T. \& W.P.M.M. van de Ven. 2011. 'Effects of purchaser competition in the Dutch health system: is the glass half full or half empty?'. Health Economics, Policy \& Law. 6:109123.

SCP (Sociaal Cultureel Planbureau). 2017. Statusscores. Available at: https://www.scp.nl/Onderzoek/Lopend_onderzoek/A_Z_alle_lopende_onderzoeken/Status scores.

Skellern. M. 2017. The Hospital as a Multi-Product Firm: The Effect of Hospital Competition on Value-Added Indicators of Clinical Quality. 'CEP Discussion Paper No. 1484'. London: Centre for Economic Performance.

Varkevisser. M., S.A. van der Geest \& F.T. Schut. 2012. 'Do patients choose hospitals with high quality ratings? Empirical evidence from the market for angioplasty in the Netherlands'. Journal of Health Economics. 31:371-378.

Varkevisser. M., S.A. van der Geest \& F.T. Schut. 2010. 'Assessing hospital competition when prices don't matter to patients: the use of time-elasticities'. International Journal of Health Care Finance and Economics. 10:43-60.

Volpp. K.G.M., S.V. Williams, J. Waldfogel, J.H. Silber, J.S. Schwartz \& M.V. Pauly. 2003. 'Market Reform in New Jersey and the Effect on Mortality from Acute Myocardial Infarction'. Health Services Research. 38(2):515-533.

WHO-FIC (World Health Organization (WHO) - Collaborating Centre for the Family of International Classifications (FIC) in Nederland). 2017. CMSV, Classificatie van Medisch Specialistische Verrichtingen. Available at: http://www.whofic.nl/Familie_van_Internationale_Classificaties/Verwante_classificaties/CMSV_Classific atie_van_Medisch_Specialistische_Verrichtingen. 


\section{Online Appendices}

\section{Appendix 1}

Dutch Classification of Procedures in Medicine procedure codes that indicate partial or full hip replacement:

$58150 ; 58160 ; 58161 ; 58162 ; 58163 ; 58164 ; 581520 ; 581523 ; 581521 ; 581522 ; 581524$; $581525 ; 581651$.

ICD-9CM diagnosis codes that indicate osteoarthrosis of the pelvic region or thigh:

71500; 71509; 71510; 71518; 71520; 71525; 71528; 71530; 71535; 71538; 71580; 71589;

71590; 71595; 71598; 71650; 71655; 71658; 71659; 71660; 71665; 71668; 71690; 71695; $71698 ; 71699$.

ICD-9CM diagnosis codes that indicate hip fractures:

$82000 ; 82001 ; 82002 ; 82003 ; 82009 ; 82010 ; 82011 ; 82012 ; 82013 ; 82019 ; 82020 ; 82021$; $82022 ; 82030 ; 82031 ; 82032 ; 8202 ; 8209$

ICD-9CM diagnosis codes that indicate pregnancy, childbirth and puerperium:

$630 ; 631 ; 632 ; 6331 ; 6339 ; 634 ; 635 ; 636 ; 637 ; 638 ; 639 ; 640 ; 6400 ; 64003 ; 641 ; 6410 ; 6411$; $6412 ; 6419 ; 642 ; 6420 ; 6431 ; 6439 ; 644 ; 6441 ; 6442 ; 645 ; 6451 ; 6452 ; 646 ; 6460 ; 6461$; $6462 ; 6463 ; 6464 ; 6465 ; 6466 ; 6467 ; 647 ; 6470 ; 6471 ; 6472 ; 6473 ; 6474 ; 6475 ; 6476 ; 648$; $6480 ; 6481 ; 6482 ; 6483 ; 6484 ; 6485 ; 6486 ; 6487 ; 6488 ; 64883 ; 6489 ; 649 ; 6490 ; 6491 ; 6492$; $6493 ; 6494 ; 6495 ; 6496 ; 6497 ; 650 ; 651 ; 6510 ; 6511 ; 652 ; 653 ; 654 ; 655 ; 65573 ; 656 ; 6560$; $65611 ; 65631 ; 65653 ; 65661 ; 657 ; 658 ; 6580 ; 65803 ; 6581 ; 6588 ; 659 ; 6591 ; 6598 ; 660$; $66001 ; 66011 ; 66041 ; 66061 ; 661 ; 6611 ; 6610 ; 6613 ; 662 ; 6621 ; 663 ; 6631 ; 6633 ; 664$; $66404 ; 66414 ; 66434 ; 665 ; 6653 ; 666 ; 66604 ; 66614 ; 667 ; 668 ; 66951 ; 66970 ; 6699 ; 670$; $67004 ; 671 ; 67144 ; 672 ; 673 ; 674 ; 675 ; 67514 ; 67594 ; 676 ; 67624 ; 678 ; 6780 ; 6781 ; 67902$ 


\section{Appendix 2}

In the Netherlands, some hospitals have multiple locations. We improve on previous research by using the hospital site-specific locations rather than the hospital's main location. Because not all treatment locations are within the same market if defined by the kilometers range, we can distinguish five different scenarios: (i) Hospital A has only one location; (ii) Hospital A1 has another treatment location (hospital A2) that lies within hospital A1's radius; (iii) Hospital A1 has another treatment location (hospital A2) that does not lie within hospital A1's radius; (iv) The competitor of hospital A (hospital B1) has multiple treatment locations (hospital B2) that do not lie within hospital A's radius and (v) The competitor of hospital A (hospital B1) has multiple treatment locations (hospital B2) that lie within hospital A's radius. Example calculations of the HHI in each scenario are given below.

SCENARIO I: HHI FOR HOSPITAL A WITH ONE LOCATION USING 30 KILOMETER RADIUS

\begin{tabular}{ccccc}
\hline Hospital & \# of beds & $\mathrm{m}_{h}$ & $\mathrm{~m}_{h}{ }^{2}$ & HHI \\
\hline A & 100 & 33.33 & 1111.11 & \\
B & 200 & 66.67 & 4444.44 & \\
Total & 300 & 100.00 & 5555.56 & 5555.56 \\
\hline
\end{tabular}

Notes: $\mathrm{m}_{h}$ is calculated by dividing the number of beds per hospital by the total number of beds in the market.

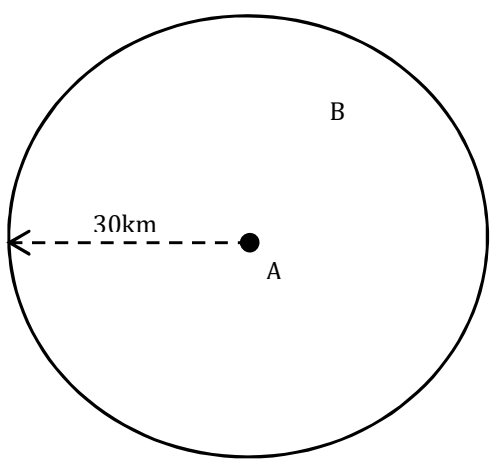

SCENARIO II: HHI FOR HOSPITAL A WITH TWO LOCATIONS USING 30 KILOMETER RADIUS

\begin{tabular}{ccccc}
\hline \multicolumn{5}{c}{} \\
Hospital & \# of beds & $\mathrm{m}_{h}$ & $\mathrm{~m}_{h}{ }^{2}$ & HHI \\
\hline A1 & 100 & & & \\
A2 & 50 & & & \\
\hline A & 150 & 17.65 & 311.42 & \\
B & 200 & 23.53 & 553.63 & \\
C & 200 & 23.53 & 553.63 & \\
D & 300 & 35.29 & 1245.67 & 2664.35 \\
Total & 850 & 100.00 & 2664.35 & 2606
\end{tabular}

Notes: $\mathrm{m}_{h}$ is calculated by dividing the number of beds per hospital by the total number of beds in the market.

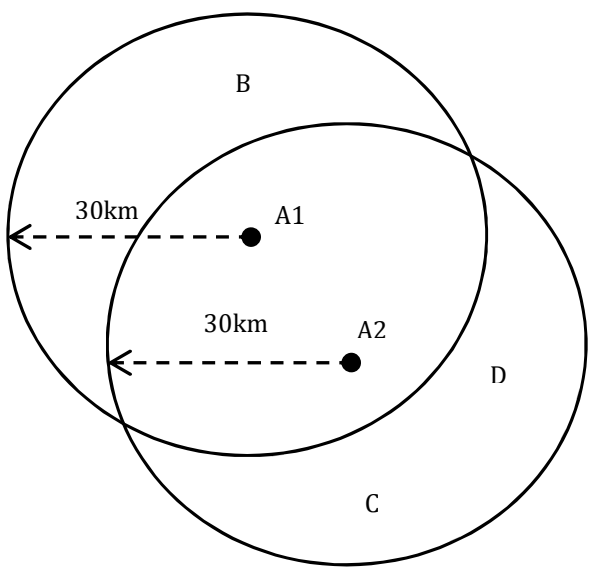


SCENARIO III: HHI FOR HOPSITAL A WITH TWO LOCATIONS (ONE NOT WITHIN THE OTHER'S RADIUS) USING 30 KILOMETER RADIUS

\begin{tabular}{ccccc} 
Hospital & \# of beds & $\mathrm{m}_{h}$ & $\mathrm{~m}_{h}{ }^{2}$ & HHI \\
\hline A1 & 100 & 33.33 & 1111.11 & \\
B & 200 & 66.67 & 4444.44 & \\
Total & 300 & 100.00 & 5555.56 & 5555.56 \\
\hline
\end{tabular}

Notes: $\mathrm{m}_{h}$ is calculated by dividing the number of beds per hospital by the total number of beds in the market.

SCENARIO IV: HHI FOR HOSPITAL A USING 30 KILOMETER RADIUS COMPETITOR (HOSPITAL B) HAS TWO LOCATIONS WHICH ARE NOT BOTH WITHIN HOSPITAL A'S RADIUS

\begin{tabular}{ccccc}
\hline Hospital & \# of beds & $\mathrm{m}_{h}$ & $\mathrm{~m}_{h}{ }^{2}$ & HHI \\
\hline A & 100 & 33.33 & 1111.11 & \\
B1 & 200 & 66.67 & 4444.44 & \\
Total & 300 & 100.00 & 5555.56 & 5555.56 \\
\hline
\end{tabular}

Notes: $\mathrm{m}_{h}$ is calculated by dividing the number of beds per hospital by the total number of beds in the market.

SCENARIO V: HHI FOR HOSPITAL A USING 30 KILOMETER RADIUS.COMPETITOR (HOSPITAL B) HAS TWO LOCATIONS WHICH ARE BOTH WITHIN HOSPITAL A'S RADIUS

\begin{tabular}{ccccc}
\hline Hospital & \# of beds & $\mathrm{m}_{h}$ & $\mathrm{~m}_{h}{ }^{2}$ & HHI \\
\hline A & 100 & 25 & 625 & \\
B1 & 200 & & & \\
B2 & 100 & & & \\
\hline B & 300 & 75 & 5625 & 6250 \\
\hline Total & 400 & 100.00 & 6250 & \\
\hline
\end{tabular}

Notes: $\mathrm{m}_{h}$ is calculated by dividing the number of beds per hospital by the total number of beds in the market.

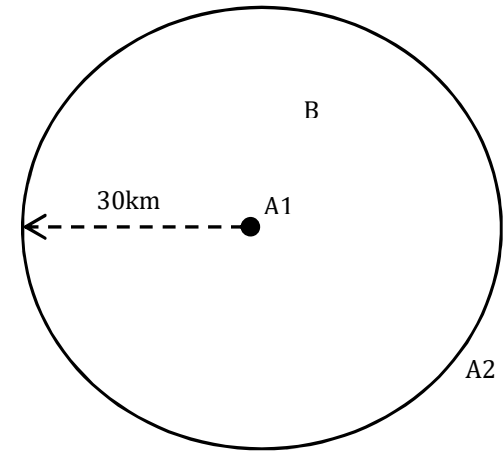

C
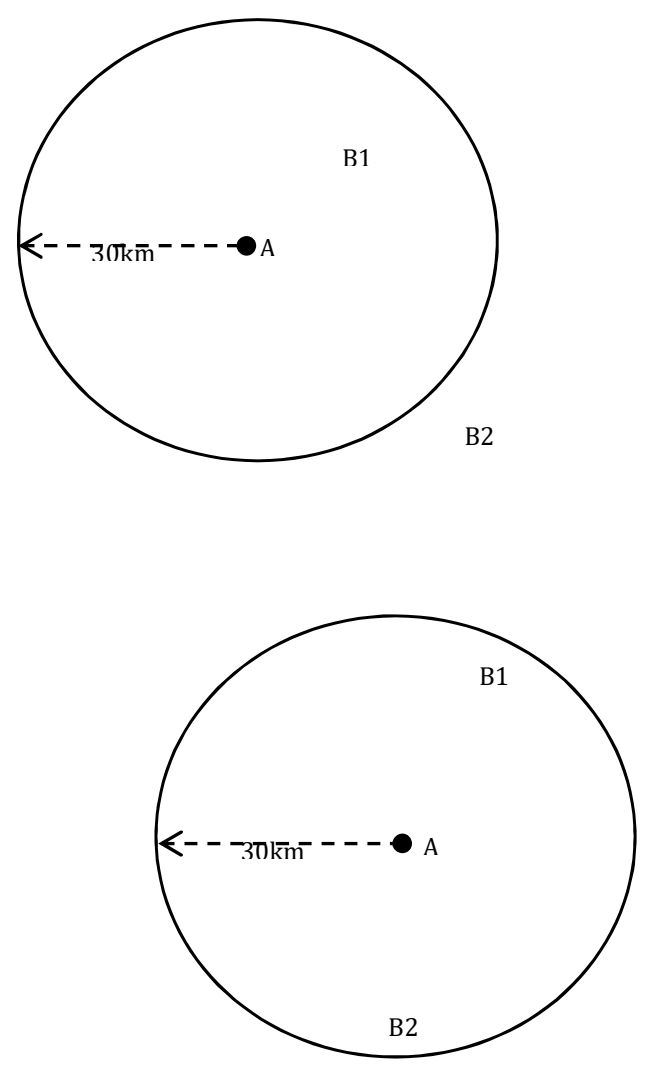


\section{Appendix 3}

TABLE A1 — ESTIMATED EFFECTS OF PRICE COMPETITION ON READMISSION RATES AFTER HIP REPLACEMENT (PRE-REFORM PERIOD)

\begin{tabular}{|c|c|c|}
\hline Radius & $\begin{array}{l}\text { 90-day readmission rates after hip } \\
\text { replacement (radius 30) }\end{array}$ & $\begin{array}{l}\text { 30-day readmission rates after hip } \\
\text { replacement (radius } 30 \text { ) }\end{array}$ \\
\hline YEAR01 & $\begin{array}{l}-0.0073 \\
(0.0050)\end{array}$ & $\begin{array}{l}-0.0053 \\
(0.0042)\end{array}$ \\
\hline YEAR02 & $\begin{array}{c}0.0004 \\
(0.0055)\end{array}$ & $\begin{array}{c}0.0043 \\
(0.0044)\end{array}$ \\
\hline YEAR03 & $\begin{array}{l}-0.0004 \\
(0.0050)\end{array}$ & $\begin{array}{l}-0.0007 \\
(0.0038)\end{array}$ \\
\hline YEAR04 (reference category) & - & - \\
\hline$\hat{\delta}_{1}(2001)$ & $\begin{array}{l}-0.0027 \\
(0.0084)\end{array}$ & $\begin{array}{l}-0.0025 \\
(0.0069)\end{array}$ \\
\hline$\hat{\delta}_{2}(2002)$ & $\begin{array}{l}-0.0110 \\
(0.0084)\end{array}$ & $\begin{array}{c}-0.0087 \\
(0.0068)\end{array}$ \\
\hline$\hat{\delta}_{3}(2003)$ & $\begin{array}{l}-0.0060 \\
(0.0084)\end{array}$ & $\begin{array}{l}-0.0029 \\
(0.0065)\end{array}$ \\
\hline Proportion female & $\begin{array}{c}0.0241 \\
(0.0526)\end{array}$ & $\begin{array}{c}-0.0470 \\
(0.0356)\end{array}$ \\
\hline Proportion age category $18-39$ (reference category) & - & - \\
\hline Proportion age category $40-64$ & $\begin{array}{c}-0.0484 \\
(0.1461)\end{array}$ & $\begin{array}{c}-0.0560 \\
(0.1142)\end{array}$ \\
\hline Proportion age category 65 and older & $\begin{array}{c}-0.0804 \\
(0.1389)\end{array}$ & $\begin{array}{c}-0.0603 \\
(0.1076)\end{array}$ \\
\hline Proportion SES score 0-5 (reference category) & - & - \\
\hline Proportion SES score 6-8 & $\begin{array}{c}0.0334 \\
(0.0571)\end{array}$ & $\begin{array}{c}0.0335 \\
(0.0497)\end{array}$ \\
\hline Proportion SES score 8-10 & $\begin{array}{c}0.0548 \\
(0.1075)\end{array}$ & $\begin{array}{c}0.0285 \\
(0.0815)\end{array}$ \\
\hline Proportion discharged to skilled nursing facility & $\begin{array}{c}0.0827 \\
(0.0412)\end{array}$ & $\begin{array}{c}0.0691 \\
(0.0300)\end{array}$ \\
\hline (intercept) & $\begin{array}{c}0.0984 \\
(0.1411)\end{array}$ & $\begin{array}{l}0.1045 \\
(0.1122)\end{array}$ \\
\hline $\mathrm{N}$ treatment hospitals & 41 & 41 \\
\hline $\mathrm{N}$ comparison hospitals & 40 & 40 \\
\hline $\mathrm{N}$ hospitals $\times$ years & 323 & 323 \\
\hline N patients & 57,648 & 57,648 \\
\hline $\mathrm{N}$ readmitted patients & 4,380 & 2,483 \\
\hline $\mathrm{R}^{2}$ & 0.63 & 0.60 \\
\hline
\end{tabular}

Notes: OLS estimates of $\hat{\delta}_{1}, \hat{\delta}_{2}$ and $\hat{\delta}_{3}$ (pretreatment years) containing hospital and year fixed effects and covariates. All estimates from regressions containing hospital and year fixed effects and covariates identified in Table 1. Charlson Score not included in this analysis as our dataset does not include information on comorbidities before 2001. Robust standard errors in parentheses. Hospitals and patients selected by criteria described in section IVB. $\mathrm{H}_{0}: \beta_{4}=\beta_{5}=\beta_{6}=0\left(\mathrm{~F}_{3,212}=0.62 ; p\right.$-value $>0.6035$ for the 90-day readmission rates and $\mathrm{F}_{3,212}=0.62 ; p$ value $>0.6007$ for the 30 -day readmission rates)

** Significant at the 5 percent level. * Significant at the 10 percent level. 
TABLE A2 - ESTIMATED EFFECTS OF PRICE COMPETITION ON READMISSION RATES AFTER HIP REPLACEMENT

\begin{tabular}{|c|c|c|c|c|c|}
\hline Radius & $\begin{array}{l}\text { 90-day } \\
\text { readmission } \\
\text { rates after hip } \\
\text { replacement } \\
\text { (radius 30) }\end{array}$ & $\begin{array}{l}\text { 90-day } \\
\text { readmission } \\
\text { rates after hip } \\
\text { replacement } \\
\text { (radius 20) }\end{array}$ & $\begin{array}{l}\text { 90-day } \\
\text { readmission } \\
\text { rates after hip } \\
\text { replacement } \\
\text { (radius 40) }\end{array}$ & $\begin{array}{l}\text { 90-day } \\
\text { readmission } \\
\text { rates after hip } \\
\text { replacement } \\
\text { (radius 50) }\end{array}$ & $\begin{array}{l}\text { 30-day } \\
\text { readmission } \\
\text { rates after hip } \\
\text { replacement } \\
\text { (radius 30) }\end{array}$ \\
\hline YEAR03 & $\begin{array}{c}-0.0043 \\
(0.0038)\end{array}$ & $\begin{array}{c}-0.0053 \\
(0.0044)\end{array}$ & $\begin{array}{c}-0.0056 \\
(0.0046)\end{array}$ & $\begin{array}{l}-0.0054 \\
(0.0046)\end{array}$ & $\begin{array}{c}-0.0032 \\
(0.0031)\end{array}$ \\
\hline YEAR04 (reference category) & - & - & - & - & - \\
\hline YEAR06 & $\begin{array}{c}0.0050 \\
(0.0048)\end{array}$ & $\begin{array}{c}0.0014 \\
(0.0048)\end{array}$ & $\begin{array}{c}0.0063 \\
(0.0055)\end{array}$ & $\begin{array}{c}0.0059 \\
(0.0072)\end{array}$ & $\begin{array}{c}0.0034 \\
(0.0035)\end{array}$ \\
\hline YEAR07 & $\begin{array}{c}0.0041 \\
(0.0048)\end{array}$ & $\begin{array}{c}0.0047 \\
(0.0050)\end{array}$ & $\begin{array}{c}0.0098 * \\
(0.0054)\end{array}$ & $\begin{array}{c}0.0105 \\
(0.0073)\end{array}$ & $\begin{array}{c}0.0009 \\
(0.0034)\end{array}$ \\
\hline$\delta$ & $\begin{array}{l}-0.0095 \\
(0.0066)\end{array}$ & $\begin{array}{l}-0.0041 \\
(0.0067)\end{array}$ & $\begin{array}{l}-0.0094 \\
(0.0061)\end{array}$ & $\begin{array}{l}-0.0084 \\
(0.0075)\end{array}$ & $\begin{array}{c}-0.0042 \\
(0.0048)\end{array}$ \\
\hline Proportion female & $\begin{array}{c}-0.0579 \\
(0.0466)\end{array}$ & $\begin{array}{c}-0.0200 \\
(0.0468)\end{array}$ & $\begin{array}{c}-0.0193 \\
(0.0468)\end{array}$ & $\begin{array}{l}-0.0170 \\
(0.0480)\end{array}$ & $\begin{array}{l}-0.0571 * \\
(0.0292)\end{array}$ \\
\hline $\begin{array}{l}\text { Proportion age category 18-39 } \\
\text { (reference category) }\end{array}$ & - & - & - & - & - \\
\hline Proportion age category $40-64$ & $\begin{array}{c}-0.2404 \\
(0.2159)\end{array}$ & $\begin{array}{l}-0.3268 * \\
(0.1940)^{*}\end{array}$ & $\begin{array}{c}-0.1690 \\
(0.1965)\end{array}$ & $\begin{array}{c}-0.1805 \\
(0.2014)\end{array}$ & $\begin{array}{l}-0.2715 \\
(0.1679)\end{array}$ \\
\hline Proportion age category 65 and older & $\begin{array}{c}-0.2397 \\
(0.2238)\end{array}$ & $\begin{array}{c}-0.3346 \\
(0.2013)\end{array}$ & $\begin{array}{l}-0.1730 \\
(0.2031)\end{array}$ & $\begin{array}{l}-0.1911 \\
(0.2097)\end{array}$ & $\begin{array}{l}-0.2433 \\
(0.1725)\end{array}$ \\
\hline $\begin{array}{l}\text { Proportion SES score } 0-5 \text { (reference } \\
\text { category) }\end{array}$ & - & - & - & - & - \\
\hline Proportion SES score $6-8$ & $\begin{array}{l}-0.0440 \\
(0.0887)\end{array}$ & $\begin{array}{l}-0.0684 \\
(0.0692)\end{array}$ & $\begin{array}{l}-0.0662 \\
(0.0714)\end{array}$ & $\begin{array}{l}-0.0485 \\
(0.0754)\end{array}$ & $\begin{array}{l}-0.0579 \\
(0.0644)\end{array}$ \\
\hline Proportion SES score $8-10$ & $\begin{array}{c}0.0529 \\
(0.1271)\end{array}$ & $\begin{array}{c}0.0661 \\
(0.1112)\end{array}$ & $\begin{array}{c}0.0563 \\
(0.1143)\end{array}$ & $\begin{array}{c}0.0682 \\
(0.1181)\end{array}$ & $\begin{array}{c}0.0244 \\
(0.0963)\end{array}$ \\
\hline Charlson Score & $\begin{array}{l}-0.3242 \\
(0.5515)\end{array}$ & $\begin{array}{l}-0.0292 \\
(0.4085)\end{array}$ & $\begin{array}{c}0.1794 \\
(0.4603)\end{array}$ & $\begin{array}{c}0.1103 \\
(0.4758)\end{array}$ & $\begin{array}{c}-0.7032 * * \\
(0.3197)\end{array}$ \\
\hline $\begin{array}{l}\text { Proportion discharged to skilled } \\
\text { nursing facility } \\
\text { (intercept) }\end{array}$ & $\begin{array}{c}-0.0113 \\
(0.0327) \\
0.3943 \\
(0.2395)\end{array}$ & $\begin{array}{l}-0.0262 \\
(0.0315) \\
0.4809 * * \\
(0.2062)\end{array}$ & $\begin{array}{c}-0.0333 \\
(0.0307) \\
0.3209 \\
(0.2095)\end{array}$ & $\begin{array}{c}-0.0272 \\
(0.0319) \\
-0.3198 \\
(0.2179)\end{array}$ & $\begin{array}{c}0.0133 \\
(0.0203) \\
0.3826 * * \\
(0.1878)\end{array}$ \\
\hline $\mathrm{N}$ treatment hospitals & 36 & 19 & 44 & 52 & 36 \\
\hline $\mathrm{N}$ comparison hospitals & 36 & 44 & 20 & 12 & 36 \\
\hline $\mathrm{N}$ hospitals $\times$ years & 287 & 247 & 249 & 245 & 287 \\
\hline $\mathrm{N}$ patients & 55,478 & 46,823 & 45,472 & 46,696 & 55,478 \\
\hline $\mathrm{N}$ readmitted patients & 5,706 & 4,788 & 4,705 & 4,787 & 1,290 \\
\hline $\mathrm{R}^{2}$ & 0.55 & 0.58 & 0.58 & 0.58 & 0.55 \\
\hline
\end{tabular}

Notes: OLS estimates of $\delta$ from regression (1). All estimates from regressions containing hospital and year fixed effects and covariates identified in Table 1. Robust standard errors in parentheses. Hospitals and patients selected by criteria described in section IVB. Radius X indicates that the estimates are based on treatment/comparison groups formed on the basis of a HHI calculated with a radius of $\mathrm{X}$ km defining the boundary of a market.

** Significant at the 5 percent level. * Significant at the 10 percent level. 
TABLE A3 - ESTIMATED EFFECTS OF PRICE COMPETITION ON READMISSION RATES AFTER HIP REPLACEMENT (POST-REFORM PERIOD DIFFERENTIATED)

\begin{tabular}{|c|c|c|c|c|c|}
\hline Radius & $\begin{array}{l}\text { 90-day } \\
\text { readmission } \\
\text { rates after hip } \\
\text { replacement } \\
\text { (radius 30) }\end{array}$ & $\begin{array}{l}\text { 90-day } \\
\text { readmission } \\
\text { rates after hip } \\
\text { replacement } \\
\text { (radius 20) }\end{array}$ & $\begin{array}{l}\text { 90-day } \\
\text { readmission } \\
\text { rates after hip } \\
\text { replacement } \\
\text { (radius } 40 \text { ) }\end{array}$ & $\begin{array}{l}\text { 90-day } \\
\text { readmission } \\
\text { rates after hip } \\
\text { replacement } \\
\text { (radius 50) }\end{array}$ & $\begin{array}{l}\text { 30-day } \\
\text { readmission } \\
\text { rates after hip } \\
\text { replacement } \\
\text { (radius 30) }\end{array}$ \\
\hline YEAR03 & $\begin{array}{l}-0.0042 \\
(0.0038)\end{array}$ & $\begin{array}{l}-0.0052 \\
(0.0044)\end{array}$ & $\begin{array}{l}-0.0055 \\
(0.0046)\end{array}$ & $\begin{array}{l}-0.0053 \\
(0.0047)\end{array}$ & $\begin{array}{l}-0.0032 \\
(0.0031)\end{array}$ \\
\hline YEAR04 (reference category) & - & - & - & - & - \\
\hline YEAR06 & $\begin{array}{l}0.0096^{*} \\
(0.0051)\end{array}$ & $\begin{array}{c}0.0036 \\
(0.0050)\end{array}$ & $\begin{array}{l}0.0115^{*} \\
(0.0063)\end{array}$ & $\begin{array}{l}0.0138 * \\
(0.0083)\end{array}$ & $\begin{array}{c}0.0055 \\
(0.0037)\end{array}$ \\
\hline YEAR07 & $\begin{array}{l}-0.0005 \\
(0.0049)\end{array}$ & $\begin{array}{c}0.0025 \\
(0.0051)\end{array}$ & $\begin{array}{c}0.0043 \\
(0.0054)\end{array}$ & $\begin{array}{c}0.0022 \\
(0.0076)\end{array}$ & $\begin{array}{l}-0.0019 \\
(0.0035)\end{array}$ \\
\hline$\hat{\delta}_{1}(2006)$ & $\begin{array}{c}-0.0189 * * \\
(0.0074)\end{array}$ & $\begin{array}{l}-0.0114 \\
(0.0079)\end{array}$ & $\begin{array}{c}-0.0170 * * \\
(0.0076)\end{array}$ & $\begin{array}{c}-0.0179 * * \\
(0.0091)\end{array}$ & $\begin{array}{l}-0.0084 \\
(0.0056)\end{array}$ \\
\hline$\hat{\delta}_{2}(2007)$ & $\begin{array}{l}-0.0000 \\
(0.0082)\end{array}$ & $\begin{array}{c}0.0040 \\
(0.0083)\end{array}$ & $\begin{array}{c}-0.0011 \\
(0.0071)\end{array}$ & $\begin{array}{c}0.0024 \\
(0.0085)\end{array}$ & $\begin{array}{c}0.0001 \\
(0.0059)\end{array}$ \\
\hline Proportion female & $\begin{array}{l}-0.0607 \\
(0.0457)\end{array}$ & $\begin{array}{l}-0.0192 \\
(0.0459)\end{array}$ & $\begin{array}{l}-0.0197 \\
(0.0459)\end{array}$ & $\begin{array}{l}-0.0099 \\
(0.0471)\end{array}$ & $\begin{array}{c}-0.0584 * * \\
(0.0289)\end{array}$ \\
\hline $\begin{array}{l}\text { Proportion age category 18-39 } \\
\text { (reference category) }\end{array}$ & - & - & - & - & - \\
\hline Proportion age category $40-64$ & $\begin{array}{l}-0.2309 \\
(0.2122)\end{array}$ & $\begin{array}{l}-0.3059^{*} \\
(0.1827)\end{array}$ & $\begin{array}{l}-0.1601 \\
(0.1958)\end{array}$ & $\begin{array}{l}-0.1641 \\
(0.2004)\end{array}$ & $\begin{array}{l}-0.2672 \\
(0.1678)\end{array}$ \\
\hline Proportion age category 65 and older & $\begin{array}{l}-0.2266 \\
(0.2195)\end{array}$ & $\begin{array}{l}-0.3179 * \\
(0.1897)\end{array}$ & $\begin{array}{l}-0.1618 \\
(0.2020)\end{array}$ & $\begin{array}{l}-0.1771 \\
(0.2085)\end{array}$ & $\begin{array}{l}-0.2374 \\
(0.1719)\end{array}$ \\
\hline $\begin{array}{l}\text { Proportion SES score } 0-5 \text { (reference } \\
\text { category) }\end{array}$ & - & - & - & - & - \\
\hline Proportion SES score 6-8 & $\begin{array}{l}-0.0349 \\
(0.0905)\end{array}$ & $\begin{array}{l}-0.0672 \\
(0.0668)\end{array}$ & $\begin{array}{l}-0.0593 \\
(0.0722)\end{array}$ & $\begin{array}{l}-0.0323 \\
(0.0773)\end{array}$ & $\begin{array}{l}-0.0538 \\
(0.0644)\end{array}$ \\
\hline Proportion SES score 8-10 & $\begin{array}{l}0.05449 \\
(0.1254)\end{array}$ & $\begin{array}{c}0.0551 \\
(0.1077)\end{array}$ & $\begin{array}{c}0.0535 \\
(0.1144)\end{array}$ & $\begin{array}{c}0.0797 \\
(0.1178)\end{array}$ & $\begin{array}{c}0.0251 \\
(0.0959)\end{array}$ \\
\hline Charlson Score & $\begin{array}{l}-0.3042 \\
(0.5579)\end{array}$ & $\begin{array}{c}0.0158 \\
(0.3855)\end{array}$ & $\begin{array}{c}0.2117 \\
(0.4489)\end{array}$ & $\begin{array}{c}0.1544 \\
(0.4686)\end{array}$ & $\begin{array}{l}-0.6942 * * \\
(0.3207)\end{array}$ \\
\hline $\begin{array}{l}\text { Proportion discharged to skilled } \\
\text { nursing facility } \\
\text { (intercept) }\end{array}$ & $\begin{array}{c}-0.00901 \\
(0.0345) \\
0.3764 \\
(0.2346)\end{array}$ & $\begin{array}{c}-0.0256 \\
(0.0340) \\
0.4622 * * \\
(0.1937)\end{array}$ & $\begin{array}{c}-0.0315 \\
(0.0320) \\
0.3050 \\
(0.2085)\end{array}$ & $\begin{array}{c}-0.0272 \\
(0.0325) \\
0.2857 \\
(0.2164)\end{array}$ & $\begin{array}{c}0.0143 \\
(0.0204) \\
0.3745 \\
(0.1863)\end{array}$ \\
\hline $\mathrm{N}$ treatment hospitals & 36 & 19 & 44 & 52 & 36 \\
\hline $\mathrm{N}$ comparison hospitals & 36 & 44 & 20 & 12 & 36 \\
\hline $\mathrm{N}$ hospitals $\times$ years & 287 & 247 & 249 & 245 & 287 \\
\hline $\mathrm{N}$ patients & 55,478 & 46,823 & 45,472 & 46,696 & 55,478 \\
\hline $\mathrm{N}$ readmitted patients & 5,706 & 4,788 & 4,705 & 4,787 & 1,290 \\
\hline $\mathrm{R}^{2}$ & 0.56 & 0.59 & 0.58 & 0.59 & 0.55 \\
\hline
\end{tabular}

Notes: OLS estimates of $\hat{\delta}_{6}$ and $\hat{\delta}_{7}$ from regression (2). All estimates from regressions containing hospital and year fixed effects and covariates identified in Table 1. Robust standard errors in parentheses. Hospitals and patients selected by criteria described in section IVB. Radius $\mathrm{X}$ indicates that the estimates are based on treatment/comparison groups formed on the basis of a HHI calculated with a radius of $\mathrm{X}$ $\mathrm{km}$ defining the boundary of a market.

** Significant at the 5 percent level. * Significant at the 10 percent level. 